UNIVERSIDADE ESTADUAL PAULISTA “JÚLIO DE MESQUITA FILHO” FACULDADE DE CIÊNCIAS AGRONÔMICAS CAMPUS DE BOTUCATU

\title{
VIABILIDADE ECONÔMICA DE TRÊS MINIUSINAS PARA PRODUÇÃO DE BIODIESEL UTILIZANDO COMO MATÉRIA PRIMA O ÓLEO DE CRAMBE (CRAMBE ABYSSINICA HOCHST).
}

Dissertação apresentada à Faculdade de Ciências Agronômicas da Unesp - Campus de Botucatu, para obtenção do título de Mestre em Agronomia (Energia na Agricultura). 
UNIVERSIDADE ESTADUAL PAULISTA “JÚLIO DE MESQUITA FILHO” FACULDADE DE CIÊNCIAS AGRONÔMICAS

CAMPUS DE BOTUCATU

\author{
VIABILIDADE ECONÔMICA DE TRÊS MINIUSINAS PARA \\ PRODUÇÃO DE BIODIESEL UTILIZANDO COMO MATÉRIA \\ PRIMA O ÓLEO DE CRAMBE (CRAMBE ABYSSINICA HOCHST).
}

ADOLFO ALEXANDRE VERNINI

ORIENTADOR: PROF. DR. OSMAR DE CARVALHO BUENO

COORIENTADOR: PROF.DR.PAULO ANDRÉ DE OLIVEIRA

Dissertação apresentada à Faculdade de Ciências Agronômicas da Unesp - Campus de Botucatu, para obtenção do título de Mestre em Agronomia (Energia na Agricultura). 
FICHA CATALOGRÁFICA ELABORADA PELA SEÇÃO TÉCNICA DE AQUISIÇÃO E TRATAMENTO DA INFORMAÇÃO - SERVIÇO TÉCNICO DE BIBLIOTECA E DOCUMENTAÇÃO - UNESP - FCA - LAGEADO- BOTUCATU (SP)

Velrnini, Adolfo Alexandre, 1962-

V537v Viabilidade econômica de três miniusinas para produção de biodiesel utilizando como matéria prima o óleo de crambe (Crambe Abyssinica Hochst) / Adolfo Alexandre Vernini.- Botucatu : [s.n.], 2014

$\mathrm{x}, 67 \mathrm{f}$. : ils. color., grafs., tabs.

Dissertação (mestrado) - Universidade Estadual Paulista Faculdade de Ciências Agronômicas, Botucatu, 2014

orientador: Osmar de Carvalho Bueno

Coorientador: Paulo André de Oliveira

Inclui bibliografia

1. Plantas oleaginosas - Cultivo. 2. Biodiesel. 3. Agricultura Familiar. 4. Desenvolvimento Sustentável. 5. Viabilidade econômica. I. Bueno, osmar de Carvalho. II. Oliveira, Paulo André de Universidade. III. Estadual Paulista "Júlio de Mesquita Filho" (Campus de Botucatu). Faculdade de Ciências Agronômicas de Botucatu. IV. Título. 
UNIVERSIDADE ESTADUAL PAULISTA “JÚLIO DE MESQUITA FILHO" FACULDADE DE CIÊNCIAS AGRONÔMICAS

CAMPUS DE BOTUCATU

\section{CERTIFICADO DE APROVAÇÃO}

TÍTULO: VIABILIDADE ECONÔMICA DE TRÊS MINIUSINAS PARA PRODUÇÃO DE BIODIESEL UTILIZANDO COMO MATÉRIA PRIMA O ÓLEO' DE CRAMBE (CRAMBE ABYSSINICA HOCHST)

ALUNO: ADOLFO ALEXANDRE VERNINI

ORIENTADOR: Prof. Dr. OSMAR DE CARVALHO BUENO CO-ORIENTADOR: Prof. Dr. PAULO ANDRÉ DE OLIVEIRA

Aprovado pela Comissão Examinadora

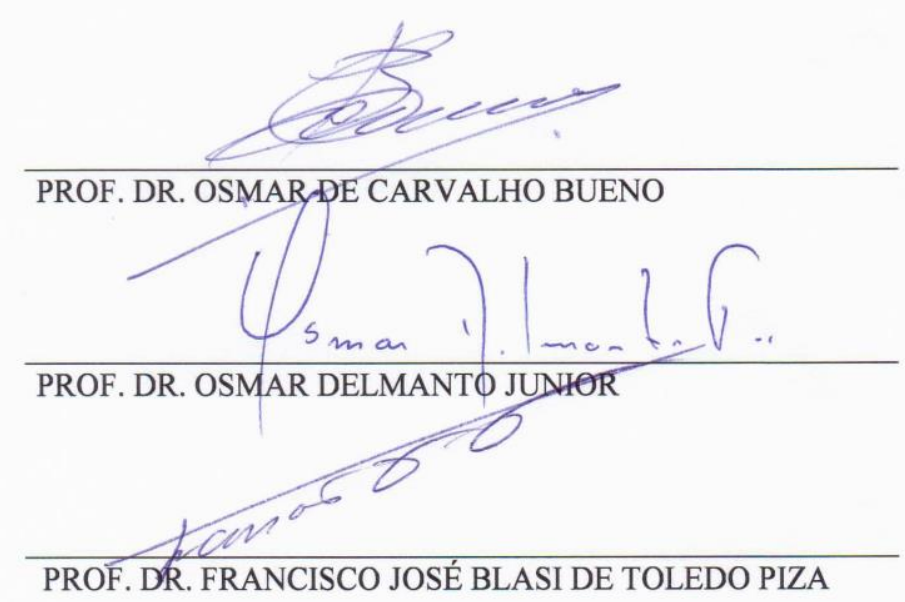

Data da Realização: 14 de agosto de 2014. 
AGRADECIMENTO ESPECIAL

Agradeço, em especial, a minha esposa, Luziana Maria Ramos Vernini, pelo incentivo, companheirismo e apoio durante todo o curso de Mestrado, e por muitas vezes acreditar mais em mim do que eu mesmo. 


\section{AGRADECIMENTOS}

Primeiramente, a Deus que tem me dado discernimento para enfrentar as situações da vida e guiar meus passos.

Aos meus pais Adolpho (in memorian) e Dirce, irmãos Valéria, Francisco e Carlos pelo apoio, carinho, e principalmente pelo incondicional amor que sempre me deram.

À Faculdade de Ciências Agronômicas (FCA - UNESP), campus de Botucatu e à Coordenadoria do Programa de Pós Graduação em Agronomia - Energia na agricultura, pela oportunidade.

Ao Prof. Dr. Osmar de Carvalho Bueno, meu orientador que se tornou um grande amigo.

Ao Prof. Dr. Paulo André de Oliveira, meu coorientador pela paciência e incentivo que tornaram possível a conclusão desta dissertação.

Aos Professores. Dr. Adriano Wagner Ballarin, Dr. Marco. A. Martin Biaggioni e Dr. Celso Fernandes Joaquim Junior pelo apoio nos momentos de dificuldades.

A todos os docentes das disciplinas cursadas pelo programa e a todos os funcionários da biblioteca Prof. Paulo de Carvalho Mattos.

Aos participantes das bancas examinadoras de qualificação e de defesa desta dissertação, Prof. Dr Osmar de Carvalho Bueno, Prof. Dr. Paulo André de Oliveira, Prof. Dr. Danilo Simões, Prof. Dr. Osmar Delmanto Junior e Prof. Dr. Francisco José Blasi de Toledo Piza.

Por fim, a todos que contribuíram caso, seus nomes não estejam mencionados, fica aqui meu reconhecimento e agradecimento pela contribuição. 


\section{SUMÁRIO}

Página

LISTA DE TABELAS ................................................................................. VIII

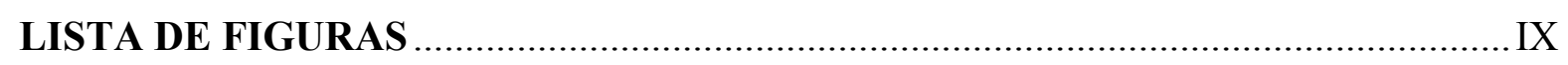

LISTA DE SIGLAS E ABREVIATURAS ...........................................................

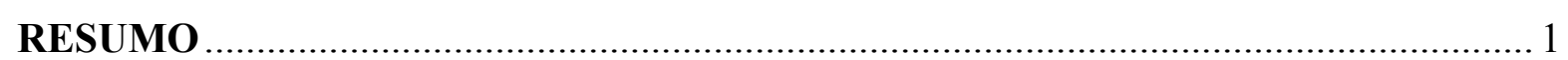

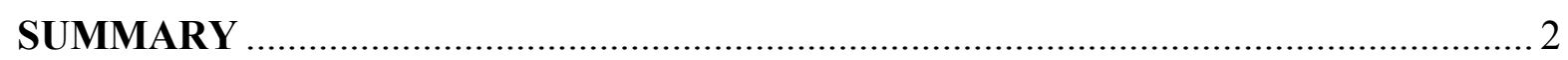

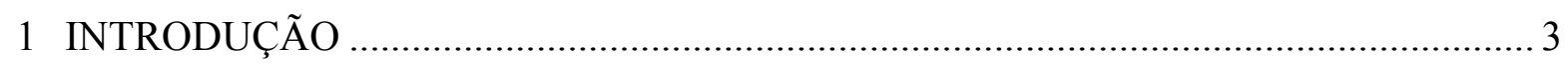

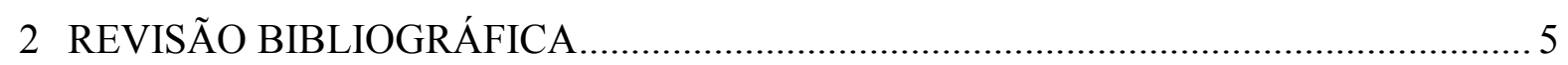

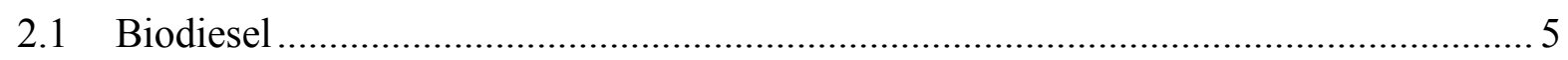

2.1.1 Aspectos tecnológicos do processo de produção de biodiesel ...................................... 7

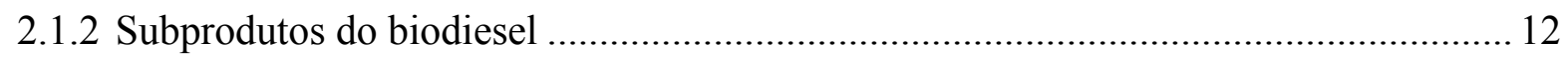

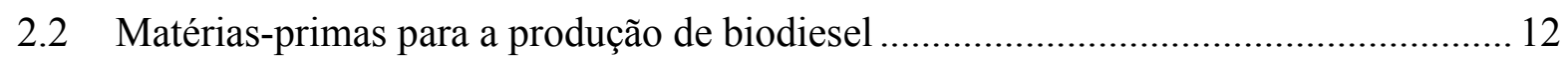

2.2.1 Características de alguns ésteres obtidos de biodiesel .............................................. 14

2.3 Efeitos do uso do biodiesel na emissão de poluentes ................................................ 15

2.4 Equipamentos básicos em uma planta de biodiesel................................................... 15

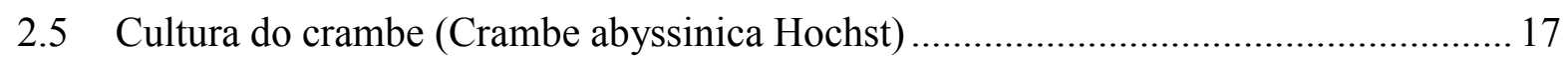

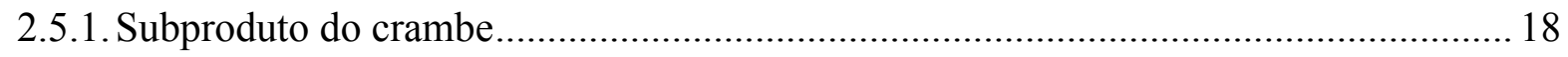

2.6 Agricultura familiar e desenvolvimento sustentável ................................................ 19

2.7 Avaliação econômica de projetos de investimentos................................................... 23

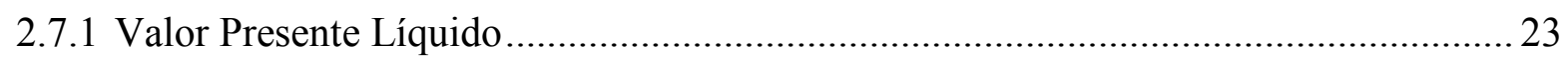

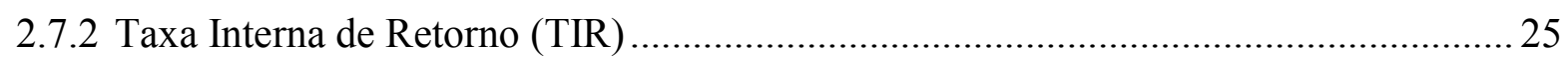

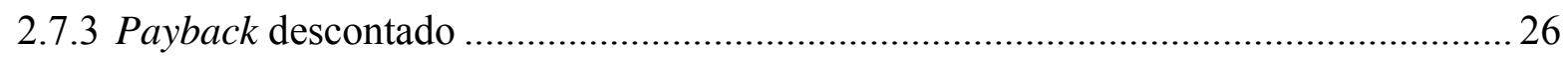

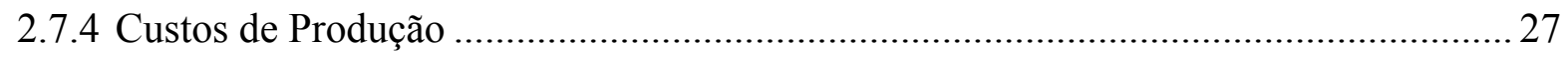

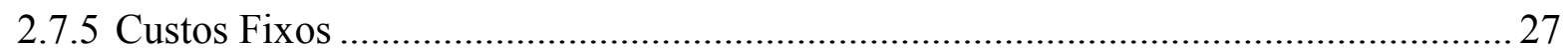

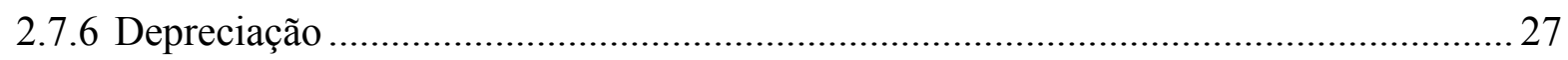

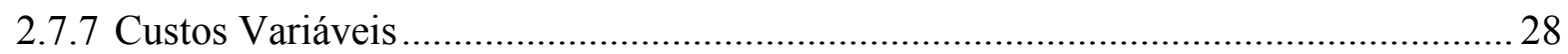

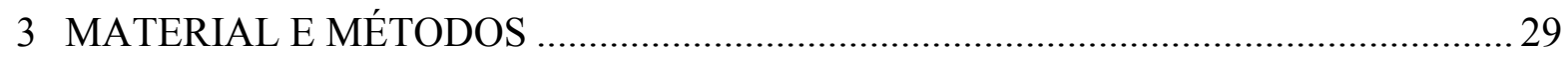

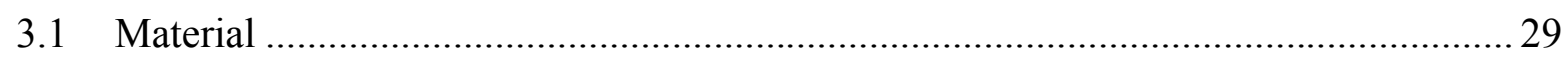

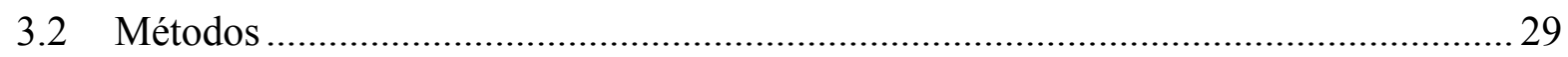




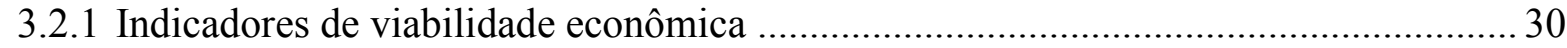

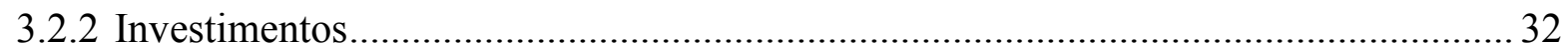

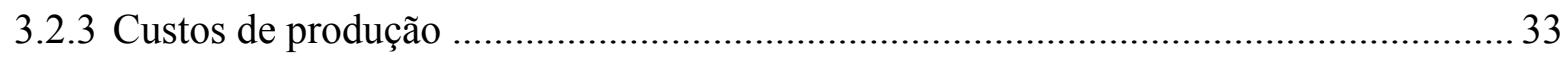

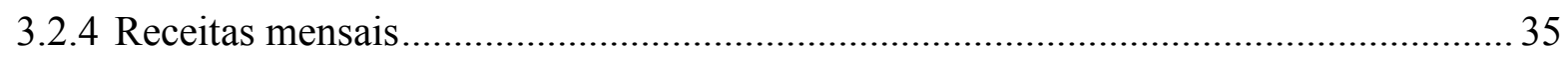

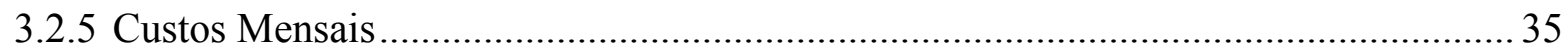

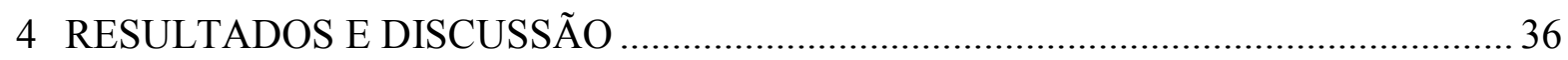

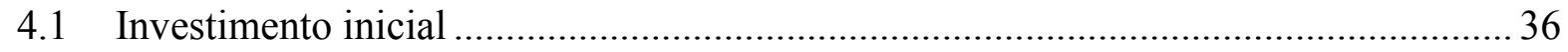

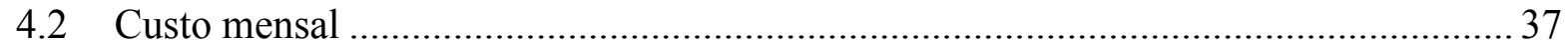

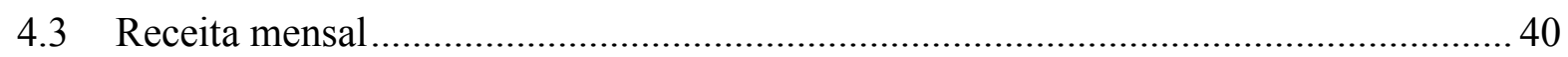

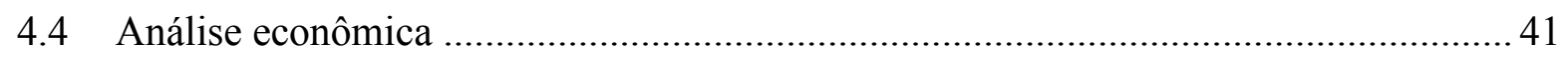

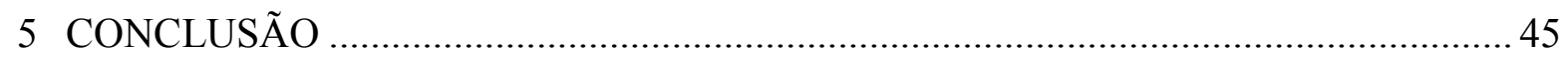

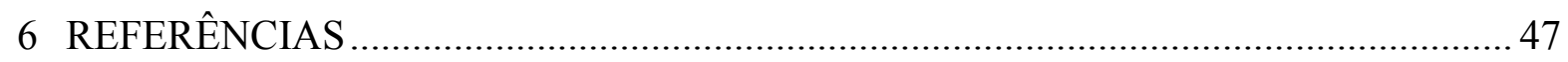

APÊNDICE 


\section{LISTA DE TABELAS}

Página

Tabela 1 - Comparação dos processos de produção de biodiesel ........................................ 10

Tabela 2 - Comparação entre ésteres metílicos e etílicos ...................................................... 11

Tabela 3 - Matérias-primas para a produção de biodiesel .................................................... 13

Tabela 4 - Ácidos graxos predominantes em óleos e gorduras ......................................... 14

Tabela 5 - Redução da emissão de gases poluentes.......................................................... 15

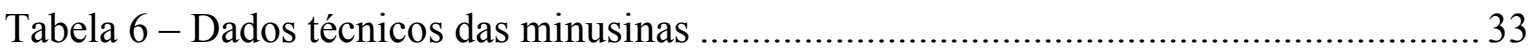

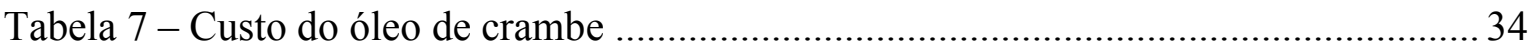

Tabela 8 - Despesa de investimento em instalações para miniusinas de biodiesel com

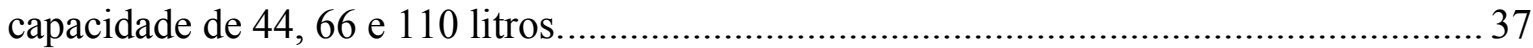

Tabela 9 - Custos mensais para miniusina de biodiesel com capacidade de 44 litros produzindo 5280 litros / mês

Tabela 10 - Custos mensais para miniusina de biodiesel com capacidade de 66 litros produzindo 7920 litros / mês

Tabela 11 - Custos mensais para miniusina de biodiesel capacidade 110 litros produzindo 13200 litros / mês

Tabela 12 - Receitas de venda mensal para miniusina de biodiesel com capacidade de 44 litros produzindo 5280 litros / mês 40

Tabela 13 - Receitas de venda mensal para miniusina de biodiesel com capacidade de 66 litros produzindo 13200 litros / mês.

Tabela 14 - Receitas de venda mensal para miniusina de biodiesel com capacidade de 66 litros produzindo 7920 litros / mês

Tabela 15 - Resultado econômico e análise da viabilidade sem impostos

Tabela 16 - Análise da viabilidade econômica com impostos. 


\section{LISTA DE FIGURAS}

Página

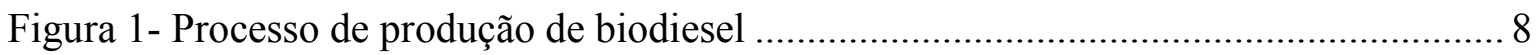

Figura 2 - Processo de reação de transesterificação ................................................................ 9

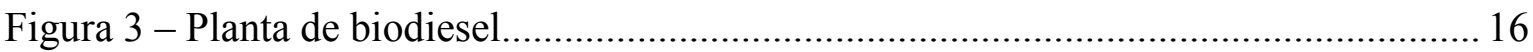


LISTA DE SIGLAS E ABREVIATURAS

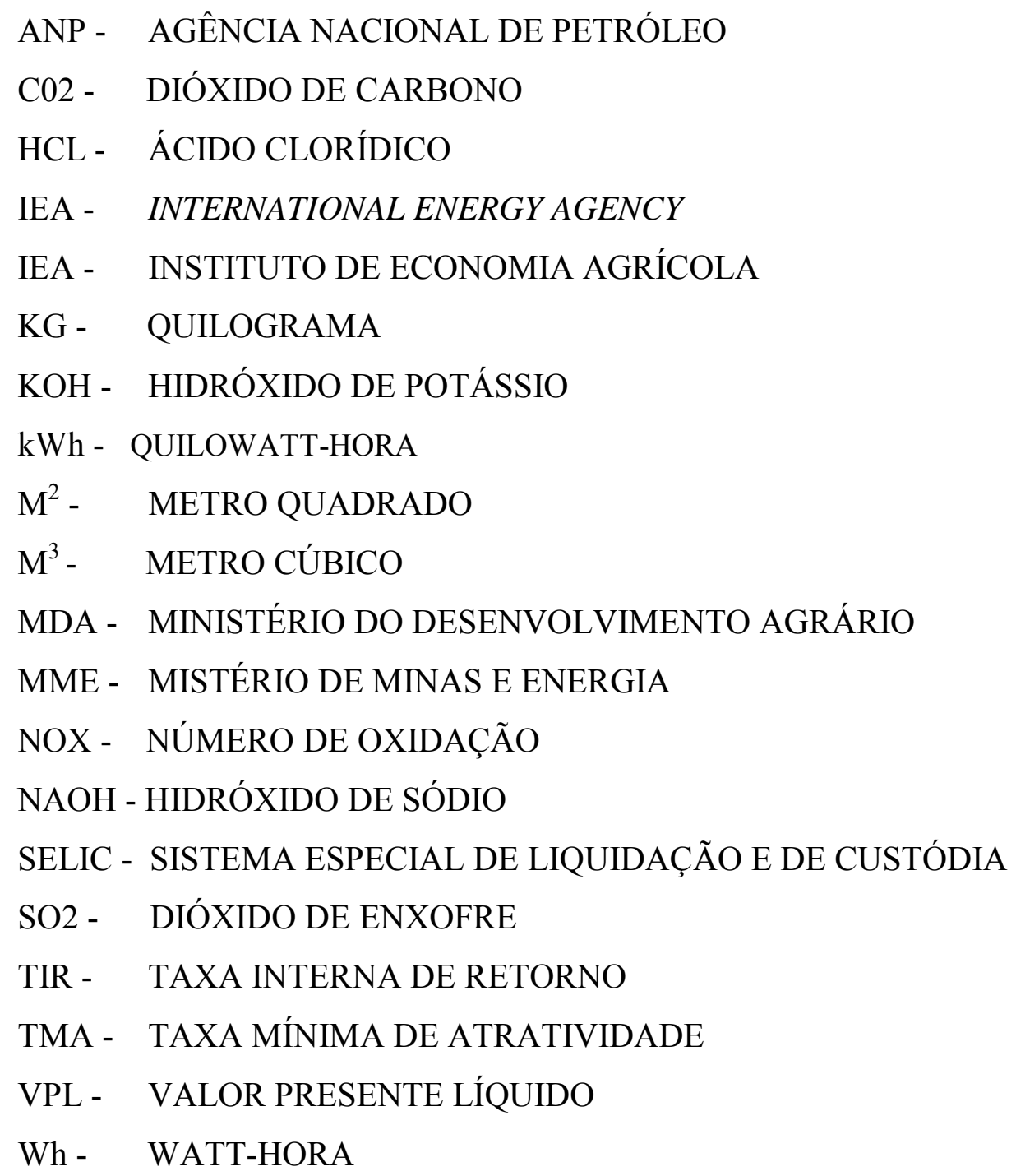




\section{RESUMO}

O objetivo deste trabalho foi realizar um estudo para identificar por meio de indicadores econômicos as melhores configurações entre três diferentes modelos produtivos de miniusinas produtoras de biodiesel com capacidade de produção de 44, 66 e 110 L.h $^{-1}$. Este trabalho utilizou os valores referentes ao custo do óleo da cultura de Crambe (Crambe abyssinica Hochst) como matéria prima para produção de biodiesel. A metodologia utilizada foi demonstrar uma descrição das instalações, a discriminação e a quantificação de todos os custos e receitas, e finalmente realizar uma análise dos indicativos de viabilidade econômica, utilizando o método do Valor Presente Líquido (VPL), a Taxa Interna de Retorno (TIR) e o Payback descontado. Após a análise dos indicadores de viabilidade econômica pode-se constatar que é viável a implantação das miniusinas de 66 e 110 L.h. ${ }^{-1}$.

Palavras-chave: Métodos. Processo. Agricultura Familiar. Desenvolvimento Sustentável. 
ECONOMIC FEASIBILITY OF THREE MINIMILLS FOR BIODIESEL PRODUCTION USING AS RAW MATERIAL OIL CRAMBE (CRAMBE ABYSSINICA HOCHST).

Botucatu, 2014. $65 \mathrm{f}$.

Author: ADOLFO ALEXANDRE VERNINI

Adviser: OSMAR DE CARVALHO BUENO

\section{SUMMARY}

This paper aimed at performing a study to identify, through economic indicators, the best settings for three different production models of biodiesel miniplants, producing 44, 66 e 110 L.h ${ }^{-1}$. The study used cost rates of Cramble oil (Crambe abyssinica Hochst) as feddstock for biodiesel production. Methodology showed facilities description as well as determining and quantifying costs and incomes. Finally, economical viability analysis was carried out using the method of Net Present Value (NPV), return internal rate (TIR) and payback discounted. After economic indicator analysis it was observed the viability for 66 and $110 \mathrm{~L} \cdot \mathrm{h}^{-1}$ biodiesel miniplants implantation.

Keywords: Methods. Process. Family Farming. Sustainable Development. 


\section{INTRODUÇÃO}

O biodiesel é uma fonte limpa e renovável de energia que pode gerar emprego e renda para o campo. Pelas estimativas do International Energy Agency IEA (2007), a escala de produção pode afetar em $25 \%$ o custo final do biodiesel, enquanto que o preço da matéria prima pode representar diferenças de até $50 \%$ do custo final. As oportunidades para produção de oleaginosas para o biodiesel tornam-se viáveis quando da rotação de culturas apresentando-se como uma alternativa econômica ao produtor rural. A escolha de uma cultura adequada em razão dos preços do produto e do seu potencial energético pode proporcionar uma rentabilidade superior a outras alternativas de cultura, inclusive com a produção do biodiesel na própria propriedade.

No Brasil, dado suas características geográficas, por se situar em uma região tropical, com altas taxas de luminosidade e temperaturas médias anuais, apresentam grandes vantagens agronômicas em relação a outros países. A disponibilidade hídrica e a regularidade de chuvas, associadas tornam-se o País com potencial para produção de energia renovável.

O Brasil explora menos de um terço de sua área agricultável, o que constitui a maior fronteira para expansão agrícola do mundo. O potencial é de cerca de 150 milhões de hectares, sendo 90 milhões referentes às novas fronteiras, e outros 60 referentes a terras de pastagens que podem ser convertidas em exploração agrícola em curto prazo (TRZECLAK, 2008).

De acordo com a ANP (2001), há também uma grande diversidade de opções para produção de biodiesel, tais como a palma e o babaçu no norte, a soja, o 
girassol e o amendoim nas regiões sul, sudeste e centro-oeste, e a mamona, que além de ser a melhor opção do semiárido nordestino, apresenta-se também como alternativa às demais regiões do país. Pode-se citar ainda o pinhão manso, colza, canola, macaúba, nabo forrageiro, algodão e crambe. Estima-se que a atual produção brasileira de biodiesel seja da ordem de 176 milhões de litros anuais.

O grande potencial agrícola do Brasil e a crescente demanda por energias renováveis permite levantar a hipótese de que mesmo miniusinas com pequenas escalas de produção podem proporcionar uma opção rentável para os produtores rurais em atividades agrícolas e não agrícolas utilizando uma cultura de maior rustidez.

O objetivo deste trabalho foi identificar por meio de indicadores econômicos as melhores configurações entre três diferentes modelos produtivos de miniusinas de biodiesel, utilizando o óleo da cultura de Crambe (Crambe abyssinica Hochst) como matéria prima. 


\section{REVISÃO BIBLIOGRÁFICA}

\subsection{Biodiesel}

De acordo com o Ministério de Minas e Energia (2010) o biodiesel, conhecido como combustível ecológico, por ser de fonte renovável, menos poluidor do que o óleo diesel utilizado em motores a combustão interna, biodegradável, entre outros benefícios, pode ser produzido de diversas matérias primas, como por exemplo, óleos vegetais, derivado de plantas oleaginosas e da polpa de alguns frutos, gordura animal (sebo), encontrada em matadouros, ou até mesmo do óleo de frituras.

Diesel (1912) o criador do motor a diesel utilizou em sua experiência o óleo de amendoim, mas atualmente, o óleo vegetal não mais pode ser utilizado in natura no motor movido a óleo diesel devido às suas propriedades, como por exemplo, a viscosidade. Se utilizado puro, pode causar danos ao motor decorrente do acúmulo de impurezas no interior do mesmo.

Knothe et al. (2006) afirmam que se a viscosidade é muito alta, como no caso dos óleos vegetais, ocorrerá a degradação da pulverização no cilindro, reduzindo a eficiência da atomização e promovendo a contaminação do óleo lubrificante e a produção de fumaça preta.

Políticas governamentais para o uso de biocombustíveis, como o etanol e o biodiesel para substituição dos derivados de petróleo vêm surgindo em todo o mundo. "Os Estados Unidos, por exemplo, planejam substituir $20 \%$ da gasolina consumida pelo país por etanol até 2017”' (CARVALHO, 2009). 
O governo brasileiro tem projetos para a produção de biodiesel, como a Lei 11.097 de 13 de janeiro de 2005, que previa o acréscimo de 5\% ao óleo diesel dentro de oito anos, sendo que nos três primeiros anos esse percentual deveria ser de $2 \%$, e assim gradativamente chegar à meta estabelecida. Quando o óleo diesel derivado de petróleo é composto por $2 \%$ de biodiesel este é chamado de $\mathrm{B} 2$, se for em $5 \%$ a adição, recebe o nome de B5, ou se for somente o biodiesel puro, recebe o nome de B100 (PNB,2005).

Atualmente a oleaginosa com maior apoio governamental é a soja, mas esta enfrenta problema com a oscilação dos preços internacionais, sendo que somente $3 \%$ da soja produzida no Brasil são encaminhados para a produção do biodiesel e com o aumento da demanda seria necessário aumentar entre quatro ou cinco vezes a quantidade de soja disponível, o que aumentaria a vulnerabilidade da cultura (MING, 2009).

O método de obtenção de biodiesel que o governo brasileiro incentiva é o de transesterificação, que consiste na reação química de triglicerídeos com álcoois (metanol ou etanol) na presença de um catalisador (ácido, básico ou enzimático) A glicerina é o subproduto do biodiesel, podendo ser utilizada para produção de sabão, por exemplo, se for corretamente purificada (SILVA; FREITAS, 2008).

Pontos positivos na utilização de plantas oleaginosas para a produção de biodiesel é o fato da mesma, durante o plantio, retirar do ar gases poluentes e depois de transformadas em biodiesel, emitir valores mais baixos desses gases. O biodiesel comparado ao óleo diesel derivado de petróleo tem [...] o $\mathrm{SO}_{2}$ totalmente eliminado, a fuligem diminuí em $60 \%$, o monóxido de carbono e os hidrocarbonetos diminuem em $50 \%$, os hidrocarbonetos poliaromáticos são reduzidos em mais de $70 \%$ e os gases aromáticos diminuem em 15\%" (BARNWAL; SHARMA, 2005, citado por SILVA; FREITAS, 2008).

Um ponto negativo encontrado nessa produção é que algumas plantas são do gênero alimentício, proporcionando assim a perda de alimento com a produção destinada ao biodiesel, ponto este desconsiderado quando o biodiesel é produzido a partir de óleos residuais de frituras, sebo ou com plantas de outro gênero, como o nabo forrageiro, utilizado para pastagem. Outro ponto negativo é que a plantação para a produção de biodiesel poderia deslocar [...] a produção de áreas cultiváveis para a produção de alimentos, aumentando problemas sociais de fome [...] (SUAREZ et al., 2009) em todo o mundo. 
Silva e Freitas (2008) alegam que [...] o biodiesel apresenta vantagens ambientais em relação ao óleo diesel; porém, o balanço energético varia conforme o sistema utilizado do cultivo das espécies produtoras de óleo [...] e ainda defendem que [...] o biodiesel é uma alternativa para a diminuição do uso do petróleo, não um substituto.

O Biodiesel é um combustível composto de mono-alquil-ésteres de ácidos graxos de cadeia longa, derivados de fontes renováveis, como óleos vegetais, gorduras animais, óleos de fritura ou gordura usados, obtidos por meio de reação de transesterificação com um álcool de cadeia curta, metanol ou etanol, a partir de catálise ácida ou básica, o subproduto obtido é a glicerina (DURÃES, 2009).

Segundo Meirelles (citado por JOQUIM JUNIOR 2010, p 6), em forma simplificada, o biodiesel é produzido através da reação de óleos vegetais ou gorduras animais com álcool (metanol ou etanol), na presença de catalisadores (hidróxido de sódio ou de potássio), resultando em um mono-alquil-éster (derivado da reação entre um ácido carboxílico e um álcool, na qual o hidrogênio do grupamento carboxila é substituído pela cadeia carbônica do álcool, formando o éster) e glicerina, como subproduto. $\mathrm{O}$ biodiesel resultante é derivado em aproximadamente $10 \%$ de sua massa do álcool reagido.

Outra forma de obtenção do biodiesel é através do processo de craqueamento térmico, no qual um reator trabalhando a altas temperaturas promove quebra das moléculas e um catalisador remove os compostos oxigenados corrosivos (SUAREZ et al., 2009).

\subsubsection{Aspectos tecnológicos do processo de produção de biodiesel}

De acordo com Marchetti (2007) tecnicamente, o biodiesel é definido como éster alquílico de ácidos graxos, obtidos da reação de transesterificação de qualquer triglicerídeo (óleo e gorduras vegetais ou animais) com álcool de cadeia curta (metanol ou etanol). A transesterificação consiste na reação química de um óleo vegetal com um álcool, que pode ser etanol ou metanol, na presença de um catalisador ácido (HCL- ácido clorídrico) ou básico (NAOH- hidróxido de sódio). Como resultado, obtém-se o éster metílico ou etílico (biodiesel), conforme o álcool utilizado, e a glicerina.

Portanto a transesterificação nada mais é do que a separação da glicerina do óleo vegetal. Durante o processo, em que ocorre a transformação do óleo 
vegetal em biodiesel, a glicerina, que compõe cerca de $20 \%$ da molécula de óleo vegetal, é removida, deixando o óleo mais fino e reduzindo suas viscosidades, e substituída pelo álcool proveniente do etanol ou metanol. A glicerina, subproduto da produção de biodiesel, pode ser utilizada como matéria- prima na produção de tintas, adesivos, produtos farmacêuticos, têxteis, aumentando e competitividade do produto. (PARENTE, 2003 citado por JOQUIM JUNIOR 2010, p 8)

A Figura 1 apresenta o diagrama esquemático do processo de produção do biodiesel.

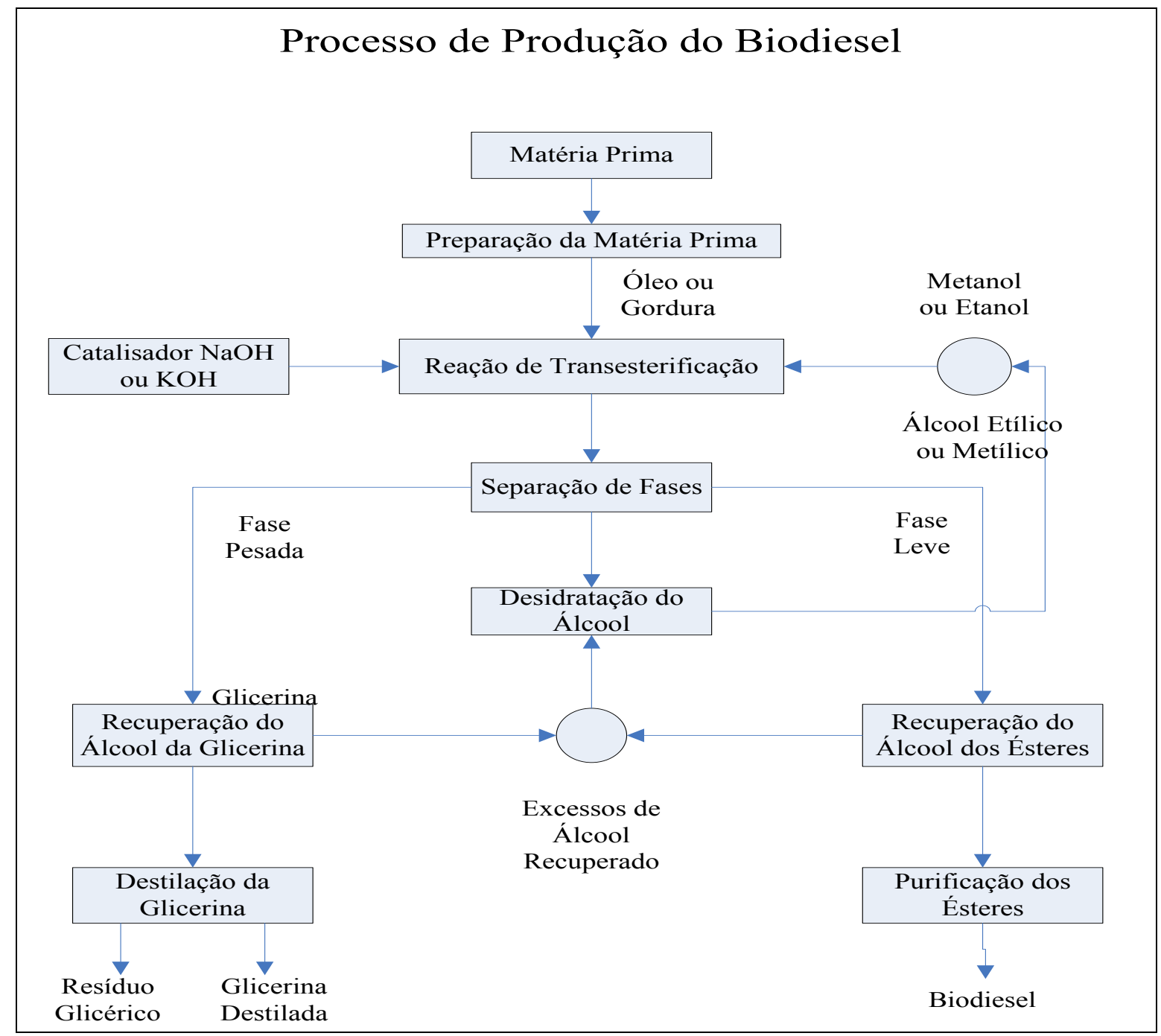

Figura 1- Processo de produção de biodiesel.

Fonte: Parente, 2003.

De acordo Meirelles (2003), a preparação da matéria-prima para sua conversão em biodiesel, visa criar as melhores condições para a efetivação da reação 
de transesterificação, com a máxima taxa de conversão. Em princípio é necessário que a matéria-prima tenha o mínimo de umidade e de acidez, o que é possível submetendo-a a um processo de neutralização, através de uma lavagem com uma solução alcalina de hidróxido de sódio ou de potássio (NAOH ou $\mathrm{KOH}$ ), seguida de uma operação de secagem ou desumidificação. As especificidades do tratamento dependem da natureza e condições da matéria graxa empregada como matéria-prima.

A Figura 2 apresenta o diagrama esquemático do processo de reação de transesterificação.

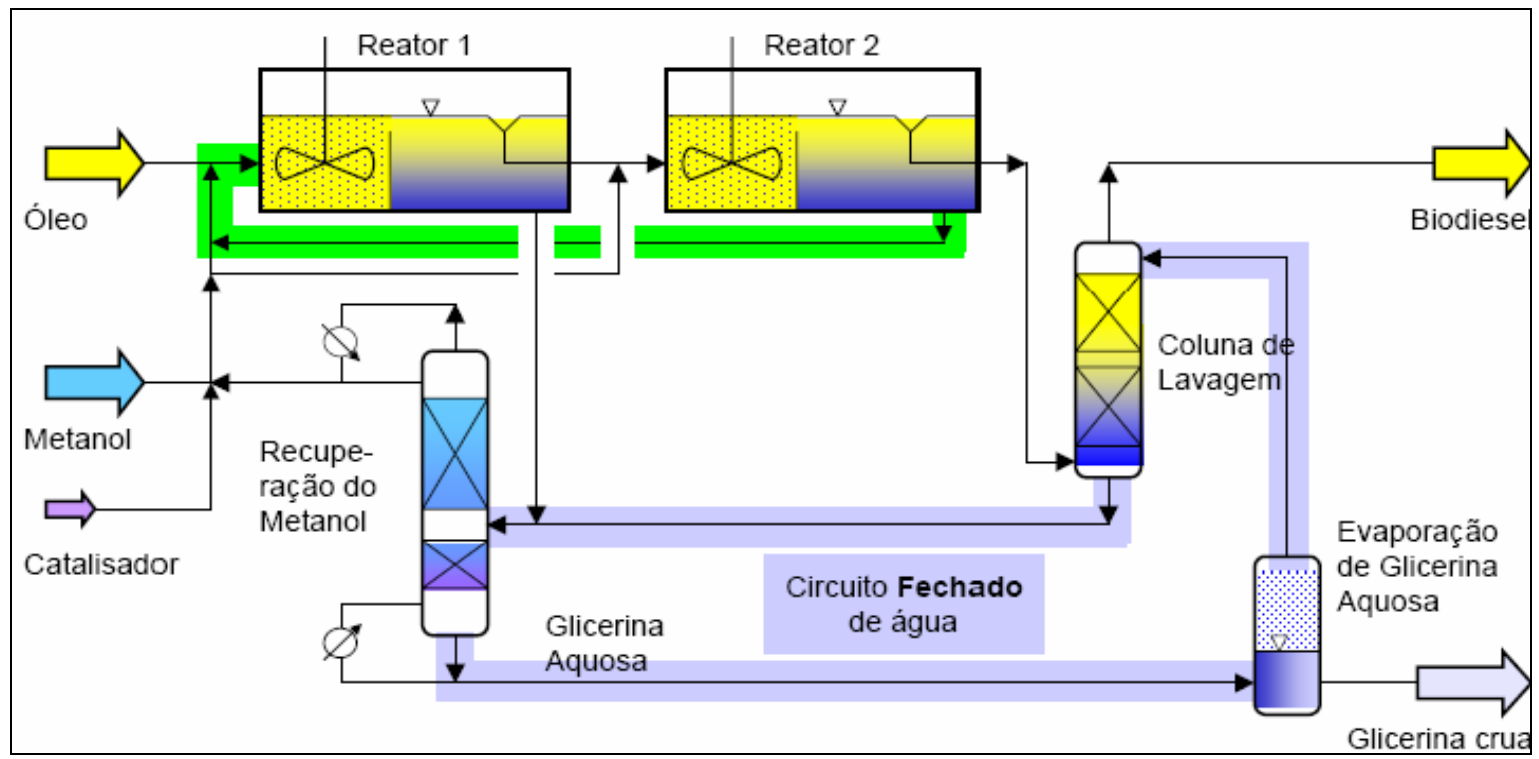

Figura 2 - Processo de reação de transesterificação.

Fonte: Durães, 2009.

De acordo com Dabdoub et al., (2009) a reação de transesterificação é a etapa da conversão, propriamente dita, do óleo ou gordura, em ésteres metílicos ou etílicos de ácidos graxos, que constitui o Biodiesel. A reação pode ser representada pela seguinte equação química, de acordo com Parente (citado por JOQUIM JUNIOR 2010, p 10): Óleo ou Gordura + Metanol $\rightarrow$ Ésteres Metílicos + Glicerol e Óleo ou Gordura + Etanol $\rightarrow$ Ésteres Etílicos + Glicerol Conforme a primeira equação química representa a reação de conversão, quando se utiliza o metanol (álcool metílico) como agente de transesterificação, obtendo-se, portanto, como produtos os ésteres metílicos que constituem o biodiesel, e o glicerol (glicerina).

Segundo Parente (2003) a segunda equação envolve o uso do etanol (álcool etílico), como agente de transesterificação, resultando como produto o biodiesel ora 
representado por ésteres etílicos, e a glicerina. Ressalta-se que, sob o ponto de vista objetivo, as reações químicas são equivalentes, uma vez que os ésteres metílicos e os ésteres etílicos têm propriedades equivalentes como combustíveis, sendo ambos, considerado biodiesel.

As duas reações acontecem na presença de um catalisador, o qual pode ser empregado, o hidróxido de sódio $(\mathrm{NAOH})$ ou o hidróxido de potássio $(\mathrm{KOH})$, usados em pequenas proporções. A diferença entre eles, com respeito aos resultados na reação, é muito pequena. No Brasil o hidróxido de sódio é muito mais barato que o hidróxido de potássio, sob o ponto de vista técnico e econômico, a reação via metanol é mais vantajosa que a reação via etanol (DURÃES, 2009).

A Tabela 1 evidencia as vantagens da produção de biodiesel pela rota metílica em relação a produção pela rota etílica.

Tabela 1 - Comparação dos processos de produção de biodiesel.

\begin{tabular}{l|c|c}
\hline \multicolumn{2}{c|}{ Quantidades e Condições Usuais Médias Aproximadas } & \multicolumn{2}{|c}{ Rota de Processo } \\
\cline { 3 - 3 } & Metílica & Etílica \\
\hline $\begin{array}{l}\text { Quantidade consumida de álcool (kg) por 1000 litros de } \\
\text { Biodiesel }\end{array}$ & & 130 \\
Excesso de álcool, recuperável, por destilação, após reação. & $100 \%$ & $650 \%$ \\
Temperatura recomendada da reação & $60^{\circ} \mathrm{C}$ & $85^{\circ} \mathrm{C}$ \\
Tempo de reação (minutos) & 45 & 90 \\
\hline
\end{tabular}
Fonte: Parente, 2003.

De acordo com Holanda (2004), no Brasil, atualmente, uma vantagem da rota etílica pode ser considerada a oferta desse álcool, de forma disseminada em todo o território nacional. Assim, os custos diferenciais de fretes, para o abastecimento do etanol versus abastecimento de metanol, em certas situações podem influenciar numa decisão. Sob o ponto de vista ambiental, o uso do etanol leva vantagem sobre o uso do metanol, quando este álcool é obtido de derivados do petróleo, no entanto, é importante considerar que o metanol pode ser produzido a partir da biomassa, quando essa suposta vantagem ecológica, pode desaparecer. Em todo o mundo o biodiesel tem sido obtido via metanol. 
A Tabela 2 apresenta uma comparação entre as características dos ésteres metílico e etílico.

Tabela 2 - Comparação entre ésteres metílicos e etílicos.

\begin{tabular}{lll}
\hline Propriedade & Éster metílico & Éster etílico \\
\hline Conversão (óleo $\rightarrow$ biodiesel) & $97,5 \%$ & $94,3 \%$ \\
Glicerina total no biodiesel & $0,87 \%$ & $1,40 \%$ \\
Viscosidade & 3,9 a $5,6 \mathrm{cSt} @ 40{ }^{\circ} \mathrm{C}$ & $\begin{array}{l}7,2 \% \text { superior ao éster } \\
\text { metílico } \\
4 \% \text { menor }\end{array}$ \\
$\Delta \%$ potência frente ao diesel & $2,5 \%$ menor & $12 \%$ maior \\
\hline
\end{tabular}
Fonte: Macedo, 2004.

Conforme Macedo (citado por JOQUIM JUNIOR 2010, p 11) após a reação de transesterificação que converte a matéria graxa em ésteres (biodiesel), a massa reacional é constituída de duas fases, separáveis por decantação e por centrifugação. A fase mais pesada é composta de glicerina bruta, impregnada dos excessos utilizados de álcool, de água, e de impurezas inerentes à matéria-prima. A fase menos densa é constituída de uma mistura de ésteres metílicos ou etílicos, conforme a natureza do álcool originalmente adotado, também impregnado de excessos reacionais de álcool e de impurezas.

Segundo Holanda (2004), a fase pesada, contendo água e álcool, é submetida a um processo de evaporação, eliminando-se da glicerina bruta esses constituintes voláteis, cujos vapores são liquefeitos num condensador. Da mesma forma, mas separadamente, o álcool residual é recuperado da fase mais leve, liberando para as etapas seguintes, os ésteres metílicos ou etílicos.

De acordo com Macedo (2004) os excessos residuais de álcool, após os processos de recuperação, contêm quantidades significativas de água, necessitando de uma separação. A desidratação do álcool é feita normalmente por destilação. No caso da desidratação do metanol, a destilação é bastante simples e fácil de ser conduzida, uma vez que a volatilidade relativa dos constituintes dessa mistura é muito grande, e praticamente inexiste o fenômeno da azeotropia.

Diferentemente, a desidratação do etanol, complica-se em razão da azeotropia associada à volatilidade relativa não tão acentuada como é o caso da separação da mistura metanol - água. Os ésteres deverão ser lavados por centrifugação e 
desumidificados posteriormente, resultando finalmente o biodiesel, o qual deverá ter suas características enquadradas nas especificações das normas técnicas estabelecidas para o biodiesel como combustível para o uso em motores de ciclo diesel (MACEDO, 2004).

Segundo Demirbas (2003), a glicerina bruta, resultante do processo, mesmo com suas impurezas convencionais, já constitui o subproduto com valor comercial. No entanto, o mercado é muito mais favorável à comercialização da glicerina purificada, quando seu valor é realçado. A purificação da glicerina bruta é feita por destilação a vácuo, resultando um produto limpo e transparente, denominado comercialmente de glicerina destilada.

\subsubsection{Subprodutos do biodiesel}

No processo de transformação do óleo em biodiesel também é gerado um subproduto que é o conhecido como glicerina (glicerol) em torno de $10 \%$ por litro, sendo que o preço pago por litro é em média de R\$ 0,6020 (SOUZA et al., 2014)

A glicerina possui uma vasta gama de aplicações, segundo Chávez (2014), em laboratórios são utilizados como agente crioprotetor de espermas, tecidos, microrganismos, enzimas, ácidos nucléicos, na elaboração de xaropes e emolientes.

De acordo com Mendes (2012), a glicerina é utilizada na indústria farmacêutica na composição de cápsulas, supositórios, anestésicos, xaropes, antibióticos e antissépticos. A glicerina é aplicada ainda como emoliente e umectante em cremes dentais, hidratantes para a pele, loções pós-barba, desodorantes, batons e maquiagens. Também é empregada no processamento de tabaco, na composição dos filtros de cigarro e como veículo de aromas. É utilizada também, como lubrificantes de máquinas processadoras de alimentos, na fabricação de tintas e resinas, na fabricação de dinamites.

De acordo com Abdalla et al. (2008), em aves, o glicerol pode ser utilizado como fonte de energia em dietas de alta produção.

\subsection{Matérias-primas para a produção de biodiesel}

Segundo Barros et al. (2008), as matérias primas para a produção de biodiesel podem ter as seguintes origens: óleos vegetais, gorduras de animais, óleos, gorduras residuais e matérias graxas de esgoto. 
A Tabela 3 apresenta o grupo, origem e obtenção das matériasprimas utilizadas para a produção de biodiesel.

Tabela 3 - Matérias-primas para a produção de biodiesel.

\begin{tabular}{llll}
\hline Grupo: & Grupo: & Grupo: & Grupo: \\
\hline $\begin{array}{l}\text { Óleos e gorduras de } \\
\text { animais }\end{array}$ & $\begin{array}{l}\text { Óleos e gorduras } \\
\text { vegetais }\end{array}$ & $\begin{array}{l}\text { Óleos residuais de } \\
\text { frituras }\end{array}$ & $\begin{array}{l}\text { Matérias graxas de } \\
\text { esgotos }\end{array}$ \\
\hline Origens: & Origens: & Origens: & Origens: \\
\hline $\begin{array}{l}\text { Matadouros, } \\
\text { frigoríficos e } \\
\text { curtumes. }\end{array}$ & $\begin{array}{l}\text { Agriculturas } \\
\text { temporárias e } \\
\text { permanentes }\end{array}$ & $\begin{array}{l}\text { Cocções comerciais } \\
\text { e industriais }\end{array}$ & $\begin{array}{l}\text { Águas residuais das } \\
\text { cidades e de certas } \\
\text { indústrias }\end{array}$ \\
\hline Obtenção: & Obtenção: & Obtenção: & Obtenção: \\
\hline $\begin{array}{l}\text { Extração com água } \\
\text { e vapor }\end{array}$ & $\begin{array}{l}\text { Extração mecânica, } \\
\text { extração solvente e } \\
\text { extração Mista }\end{array}$ & $\begin{array}{l}\text { Acumulações e } \\
\text { coletas }\end{array}$ & $\begin{array}{l}\text { Processos em fase } \\
\text { de pesquisa e } \\
\text { desenvolvimento }\end{array}$ \\
\hline
\end{tabular}

Fonte: Macedo, 2004.

De acordo com Barros et al. (2008), todos os óleos vegetais, enquadrados na categoria de óleos fixos ou triglicerídeos, podem ser transformados em biodiesel. Dessa forma, poderiam constituir matéria prima para a produção de biodiesel, os óleos das seguintes espécies vegetais: soja, grão de amendoim, polpa do dendê, amêndoa do coco de dendê, amêndoa do coco da praia, caroço de algodão, amêndoa do coco de babaçu, semente de girassol, semente de mamona, semente de crambe, semente de colza, semente de maracujá, polpa de abacate, caroço de oiticica, semente de linhaça, semente de tomate, entre muitos outros vegetais em forma de sementes, amêndoas ou polpas.

Segundo Aranda (2005), os óleos e gorduras de animais possuem estruturas químicas semelhantes as dos óleos vegetais, sendo moléculas triglicerídeas de ácidos graxos. As diferenças estão nos tipos e distribuições dos ácidos graxos combinados com o glicerol.

A Tabela 4 apresenta os ácidos graxos predominantes em óleos e gorduras. 
Tabela 4 - Ácidos graxos predominantes em óleos e gorduras.

\begin{tabular}{lll} 
Óleo de soja & Óleo de babaçu & Sebo bovino \\
\hline Ácido oléico & Ácido laurídico & Ácido esteárico
\end{tabular}

Fonte: Macedo, 2004.

De acordo com Biocombustíveis (2009), existem alguns problemas técnicos com respeito à transformação dos óleos residuais de frituras, face a heterogeneidade da matéria-prima com respeito ao grau de acidez, do teor de umidade e da presença de certos contaminantes. Mesmo com esses problemas, pelo ponto de vista ambiental, o óleo de fritura utilizado na produção de biodiesel ainda é vantajoso. Para empresas que precisam obter certificação ISO 14000, que por ser mais rigorosa na questão ambiental, precisam dar destinos adequados aos resíduos, ora por razões econômicas, ora por questões ambientais, na tentativa de reduzir o impacto ambiental causado pelo homem.

O mesmo autor explica sobre o uso de óleos e gorduras residuais de esgotos: Esta possibilidade reveste-se de extraordinária importância não somente pela abundância dessa matéria prima, como também um artifício para evitar a transformação dessa matéria graxa em metano, um danoso contribuinte para o efeito estufa.

\subsubsection{Características de alguns ésteres obtidos de biodiesel}

Segundo Aranda (citado por JOQUIM JUNIOR 2010, p 19), em função das diferentes origens, os ésteres de biodiesel possuem características que os diferenciam descritas a seguir:

- Biodiesel etílico de soja: apresenta estabilidade à oxidação e teor de fósforo, que podem potencializar a formação de sabões e ácidos graxos.

- Biodiesel etílico de palma (dendê): a acidez da matériaprima e suas propriedades a frio podem causar problemas de entupimento de bicos injetores em motores.

- Biodiesel metílico de mamona: apresenta viscosidade de $11 \mathrm{~mm}^{2} / \mathrm{s}$, muito acima do especificado para B2, entre 1,9 a $6,0 \mathrm{~mm}^{2} / \mathrm{s}$.

- Biodiesel de óleo de fritura: sua utilização depende de pré-tratamento da matéria-prima. 
- Biodiesel proveniente de sebo: contém ácidos graxos livres e ácidos graxos saturados, insaponificáveis, requerendo cuidados no que se referem as suas propriedades a baixas temperaturas, requerendo aditivações.

\subsection{Efeitos do uso do biodiesel na emissão de poluentes}

De acordo com Quintella et al. (2009), em termos ambientais, uma das mais expressivas vantagens trazidas pelo biodiesel refere-se à redução da emissão de gases poluentes, Tabela 5 .

Tabela 5 - Redução da emissão de gases poluentes.

\begin{tabular}{llllll}
\hline Poluente & Redução/ Aumento & \multicolumn{5}{c}{ Percentual (\%) } \\
& & $\mathrm{B} 100$ & $\mathrm{~B} 20$ & $\mathrm{~B} 10$ & $\mathrm{~B} 5$ \\
Gases do efeito estufa & $\mathrm{R}$ & 78 & 15 & 7,5 & 3,75 \\
Enxofre & $\mathrm{R}$ & 19 & 19 & 9,5 & 4,95 \\
Material particulado & $\mathrm{R}$ & 10 & 10 & 5,0 & 2,5 \\
$\mathrm{NO}_{\mathrm{x}}$ & $\mathrm{A}$ & 13 & 2,5 & 1,3 & 0,65 \\
\hline
\end{tabular}

Fonte: Meirelles, 2003.

O mercado de créditos de carbono nasceu em dezembro de 1997 com a assinatura do Protocolo de Kyoto. Nele foram estabelecidas metas de redução de gases poluentes pelos países desenvolvidos, que se comprometeram em reduzir as emissões, em média, 5 \% abaixo dos níveis registrados em 1990, para o período entre 2008 e 2012, o ganho decorrente da redução da emissão de $\mathrm{CO}_{2}$, por queimar um combustível mais limpo, pode ser estimado em cera de 2,5 toneladas de $\mathrm{CO}_{2}$ por tonelada de biodiesel (LUCEMA, 2004).

\subsection{Equipamentos básicos em uma planta de biodiesel}

De acordo com De Lorenzo (2014), Figura 3 os principais equipamentos básicos em uma planta de biodiesel correspondem a:

- Tanques de armazenagem de matérias-primas: tanques cilíndricos verticais destinados à armazenagem do óleo vegetal e do álcool (metanol ou etanol) a serem utilizados no processo. 
- Pré-aquecedor de óleo (secador): vaso cilíndrico vertical, dotado de sistema de geração de vácuo e aquecimento (por vapor, água quente ou elétrica). Neste equipamento, o óleo, previamente decantado e filtrado é aquecido e desidratado a vácuo. Pode ser utilizado no início do processo, como secador de óleo ou no seu final, como secador do biodiesel após o processo de lavagem, quando aplicado.

- Secador: equipamento similar ao utilizado no préaquecimento.

- Reator de transesterificação: vaso cilíndrico vertical, dotado de sistema de aquecimento (por vapor, água quente ou elétrico) e de sistema de mistura por recirculação ou por meio de agitação mecânica. Possui sistema de regulagem de pressão e vácuo para controle dos parâmetros do processo.

- Tanques de decantação: com geometria similar a do reator os tanques de decantação destinam-se a separação do biodiesel, mais claro e menos denso, do glicerol, mais denso e mais escuro, o qual se sedimenta no fundo do vaso.

- Lavadoras: utilizadas para a remoção de resíduos de metanol, catalisador e outras impurezas, através da lavagem por contato com água.

A Figura 3 apresenta os principais equipamentos básicos em uma planta de biodiesel.

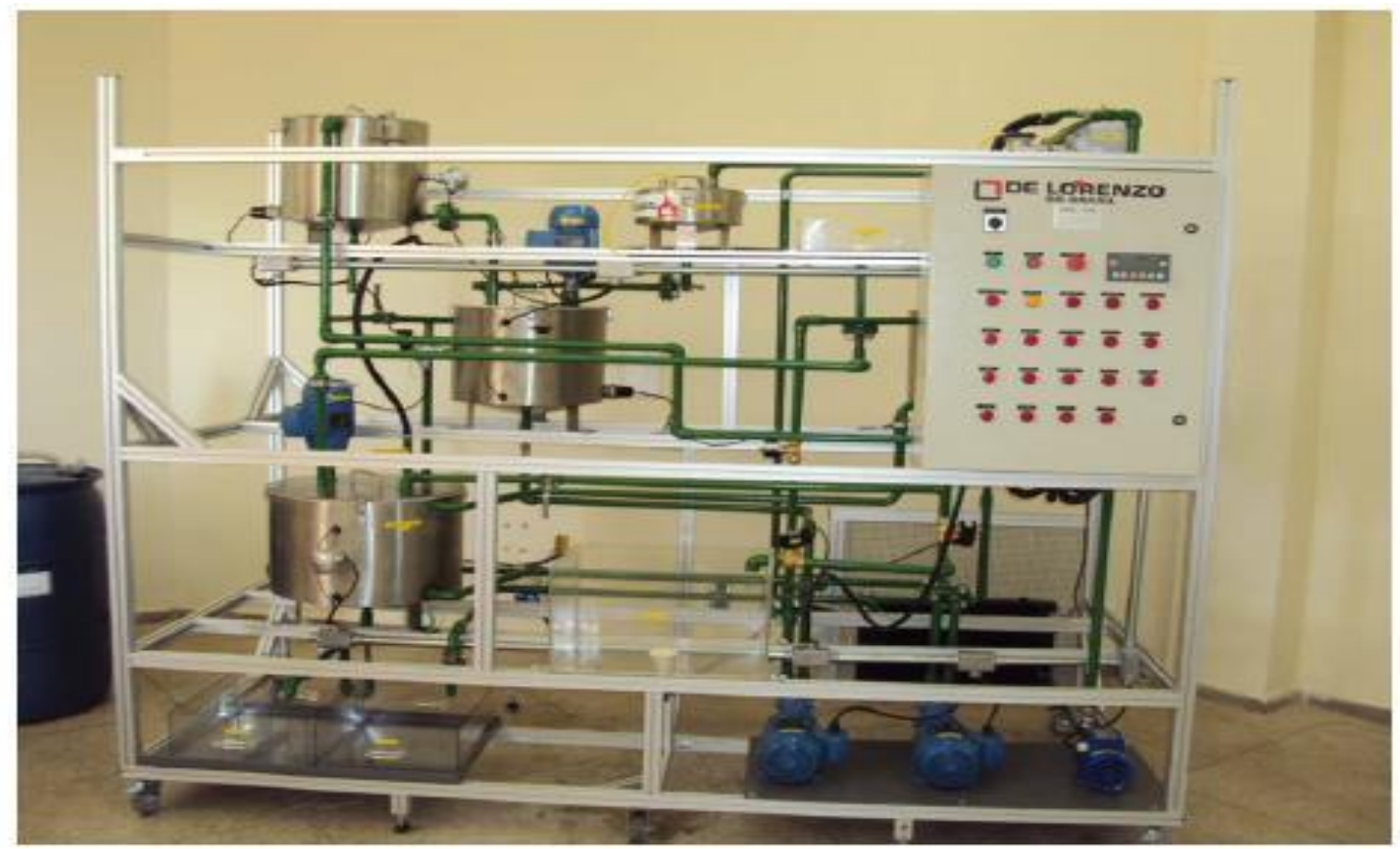

Figura 3 - Planta de biodiesel. Fonte: De Lorenzo, 2014. 


\subsection{Cultura do crambe (Crambe abyssinica Hochst)}

Originário da Etiópia, país africano de clima quente e seco, e domesticado na Europa, na região do Mediterrâneo, o crambe pertence à família das crucíferas, a mesma da colza e da canola. Como tem um ciclo médio de 90 dias, é indicado como excelente alternativa para a safrinha, em especial para produtores de soja e de milho, no sistema de rotação de culturas (COSTA, 2010).

De acordo com Machado (2007), no início das pesquisas, durante os anos 90, eram analisadas as vantagens da planta como forrageira para a rotação de culturas e cobertura de solos no inverno. Porém, mais que uma opção para a safrinha na região dos cerrados, seu uso mostrou um potencial muito maior quando então foi descoberta a boa capacidade de produção de óleo vegetal de suas sementes. O grão é mais uma matéria-prima para a geração de biodiesel, uma das grandes apostas do governo federal na oferta futura de combustíveis renováveis.

De acordo com Brandão (2013), a produção rápida, a rusticidade da cultura, a fácil adaptação do plantio e o custo baixo da atividade, que não exige novas máquinas e equipamentos e tem método simples de extração de óleo por meio de prensa ou extrusora, também são características adequadas para a agricultura familiar, segmento econômico visto como importante produtor de oleaginosas para a produção de biodiesel.

O óleo ainda é insumo para a indústria química fabricar polímeros, lubrificantes e plásticos. Embora tóxico para suínos e aves, o farelo é rico em nutrientes e pode ser adicionado na alimentação de bovinos, até $5 \%$ da ração do gado com segurança (ANTONELLI, 2012).

Segundo Pitol et al. (2010), seguem descritos abaixo os cuidados no campo com relação à produção do crambe:

- plantio: o solo para o cultivo de crambe deve ser eutróficos ou corrigido. A boa fertilidade é mais importante que a adubação na semeadura. Para o desenvolvimento do sistema radicular pivotante da planta, é necessário que haja boas condições na primeira camada do terreno, numa profundidade entre 20 e 40 centímetros. Solo descompactado permite o aprofundamento da raiz e, assim, torna o crambe capaz de suportar o tempo seco. Plantio em solos ácidos e com alumínio tóxico devem ser evitados, pois nessas condições ocorre perda de produtividade e a cultura perde tolerância à seca. 
- espaçamento: deve ser de 17 a 45 centímetros entre as linhas. Vale ressaltar que, quanto menor a distância, mais competitivo torna-se o crambe em relação às plantas invasoras. Não há herbicidas seletivos para plantas invasoras de folha larga.

- ambiente: o crambe é tolerante ao clima seco e também a temperaturas baixas e geadas, desde que não seja exposto a essas condições na fase de plântula e florescimento. Alta umidade do ar ou chuvas frequentes a partir do florescimento é prejudicial, pois favorece o ataque de doenças. A fase de fixação da planta, no entanto, exige boa umidade.

- cuidados: a planta é pouco atacada por pragas devido à presença do glucosinolato, substância tóxica presente nas folhas e hastes. Porém, a recomendação é evitar semeadura do crambe em áreas muito praguejadas. A ocorrência de doenças está relacionada a condições de alta umidade do ar ou a chuvas frequentes após o florescimento. Contudo, em condições de clima seco não há incidência de doenças.

- produção: em 35 dias de plantio, a planta floresce e a colheita pode ser iniciada em 85 a 90 dias. O plantio é recomendado nos meses de abril, maio e junho sendo possíveis três safras ao ano. Quando está madura, pronta para ser colhida, a cultura apresenta uma coloração marrom-clara. Devido à facilidade e à praticidade, a colheita é mecanizada. Mas em pequenas áreas pode-se fazer colheita manual, devendo fazer o corte antes da maturação total para diminuir as perdas por debulha. O crambe chega a 90 centímetros de altura e apresenta maturação.

\subsubsection{Subproduto do crambe}

No processo de extração do óleo de crambe, é gerado um subproduto que é a torta de crambe em média de $63 \%$ cada $1 \mathrm{~kg}$, e o preço pago por $1 \mathrm{~kg}$ de torta de crambe é em média de R\$ 0,5129 (SOUZA et al., 2014).

A torta de crambe pode ser utilizada para produção de etanol, conforme estudo da viabilidade de produção de álcool etílico a partir da celulose presente na torta de crambe (Crambe abyssinica Hochst), (SORES, 2011), substituição de farelo de soja por torta de crambe (Crambe abyssinica Hochst), para ovinos em crescimento (SILVA, 2013), na alimentação de cordeiros, substituição, em níveis crescentes, da 
proteína do farelo de soja pela proteína da torta de crambe, na dieta de cordeiro (CANOVA, 2012).

Existem estudos sobre o equilíbrio de adsorção da torta prensada de crambe (crambe abyssinica Hochst) em sua aplicação como biosorvente em soluções aquosas de corante (OLIVEIRA, 2009). Também pode ser aplicada na composição bromatológica e níveis de inclusão na suplementação de bovinos de corte (OLIVEIRA, 2010).

A Empresa Brasileira de Pesquisa Agropecuária (EMBRAPA) estuda o crambe na alimentação de ovinos. Os primeiros resultados indicam que a torta de crambe poderá substituir em até $90 \%$ o farelo de soja na composição de dietas de ruminantes (FARMPOINT, 2014). A torta de crambe pode ser utilizada na alimentação de bovinos leiteiros (HERCULANO, 2014), sendo rico em nutrientes e pode ser adicionado na alimentação de bovinos, até 5\% da ração do gado com segurança ( BIANCHINI, 2013).

\subsection{Agricultura familiar e desenvolvimento sustentável}

A agricultura familiar não é uma categoria social recente, nem a ela corresponde uma categoria analítica nova na sociologia rural. "No entanto, sua utilização, com o significado e abrangência que lhe tem sido atribuído nos últimos anos, no Brasil, assume ares de novidade e renovação" (WANDERLEY, 2001).

O modelo familiar teria como característica a relação íntima entre trabalho e gestão, a direção do processo produtivo conduzido pelos proprietários, a ênfase na diversificação produtiva e na durabilidade dos recursos e na qualidade de vida, a utilização do trabalho assalariado em caráter complementar e a tomada de decisões imediatas, ligadas ao alto grau de imprevisibilidade do processo produtivo (FAO/INCRA, 1994).

A agricultura familiar além de produzir alimentos e matériasprimas, gera mais de $80 \%$ da ocupação no setor rural e favorece o emprego de práticas produtivas ecologicamente mais equilibradas, como a diversificação de cultivos, o menor uso de insumos industriais e a preservação do patrimônio genético. Assim, o meio rural, sempre visto como fonte de problemas, hoje aparece também como portador de soluções, vinculadas à melhoria do emprego e da qualidade de vida (WANDERLEY, 2001). 
O Brasil Rural precisa de uma estratégia de desenvolvimento, visando à maximização das oportunidades de desenvolvimento humano em todas as regiões do país diversificando as economias locais a começar pela própria agropecuária. (VEIGA, 2001).

Veiga (2006) observa o brutal poder devorador de postos de trabalho da atual modernização das grandes lavouras, exemplificado no caso da cana-deaçúcar, onde a demanda de força de trabalho foi cortada pela metade nos anos 90, apesar da expansão de $10 \%$ da área cultivada.

O modelo "produtivista", de necessário aumento da produção e da produtividade, orientado para as funções da agricultura como fornecedora de alimentos baratos, matérias-primas e divisas, tem cedido lugar à ótica da multifuncionalidade, mesmo que esse termo seja muito polêmico por ter sido utilizado pela União Europeia para justificar a manutenção dos subsídios agrícolas. Nesses países, a agricultura se apresenta não apenas como fornecedora de bens, senão também de serviços tangíveis e intangíveis, como os serviços ambientais e procura responder também a certas aspirações simbólicas da sociedade, como a preservação da paisagem e da cultura local (ALMEIDA, 1995).

Segundo Beduschi (2004), além disso, a agricultura familiar está associada à dimensão espacial do desenvolvimento, por permitir uma distribuição populacional mais equilibrada no território, em relação à agricultura patronal, normalmente associada à monocultura. Estas ideias devem ser contextualizadas no debate sobre os caminhos para a construção do desenvolvimento sustentável.

Recentemente, vem sendo defendida uma perspectiva que reforça as ideias acima apresentadas é a dimensão territorial do desenvolvimento rural, onde as atividades agrícolas e não agrícolas devem ser integradas no espaço local, perdendo sentido a tradicional divisão urbana/rural e ultrapassando o enfoque predominantemente setorial (agrícola) do espaço rural. No âmbito das políticas públicas, isto se traduziu na criação da SDT (Secretaria do Desenvolvimento Territorial), subordinada ao MDA (BEDUSCH, 2004).

Todavia, mesmo havendo consenso entre vários autores sobre a importância da agricultura familiar, as visões em relação ao modelo que essa agricultura familiar deveria adotar divergem em certos aspectos.

Já Abramovay (1992) diferencia a agricultura familiar no interior das sociedades capitalistas mais desenvolvidas como uma forma completamente diferente 
do campesinato clássico. Enquanto que os camponeses podiam ser entendidos como "sociedades parciais com uma cultura parcial, integrados de modo incompleto a mercados imperfeitos", representando um modo de vida caracterizado pela personalização dos vínculos sociais e pela ausência de uma contabilidade nas operações produtivas. Já a agricultura familiar, segundo o mesmo autor, [...] é altamente integrada ao mercado, capaz de incorporar os principais avanços técnicos e de responder as políticas governamentais [...] Aquilo que era antes de tudo um modo de vida converteu-se numa profissão, numa forma de trabalho.

De acordo com o mesmo autor, em lhe sendo favorável esse ambiente e com apoio do Estado, a agricultura familiar preencherá uma série de requisitos, dentre os quais fornecerem alimentos baratos e de boa qualidade para a sociedade e reproduzir-se como uma forma social engajada nos mecanismos de desenvolvimento rural.

O pensamento do autor acima citado fica claramente evidenciado quando expressa que "Se quisermos combater a pobreza, precisamos, em primeiro lugar, permitir a elevação da capacidade de investimento dos mais pobres. Além disso, é necessário melhorar sua inserção em mercados que sejam cada vez mais dinâmicos e competitivos".

Segundo Altieri (2002), existe uma visão em que o agricultor familiar está fortemente inserido nos mercados e procura sempre adotar novas tecnologias. Em contraposição, há uma corrente que tem sido caracterizada como "neopopulismo ecológico", que destaca a autonomia relativa do pequeno produtor, enfatizando a utilização de recursos locais, a diversificação da produção e outros atributos que apontam para a sustentabilidade dos sistemas de produção tradicionais. Nessa visão, a sobrevivência do agricultor familiar teria muito mais de resistência do que de funcionalidade à lógica da expansão capitalista.

Este segundo enfoque está associado ao que se conhece como agroecologia. Na agroecologia, os objetivos de um programa de desenvolvimento rural seriam (ALTIERI, 2002):

- Segurança alimentar com valorização de produtos tradicionais e conservação de germoplasma de variedades cultivadas locais;

- Resgatar e reavaliar o conhecimento das tecnologias camponesas;

- Promover o uso eficiente dos recursos locais;

- Aumentar a diversidade vegetal e animal de modo a diminuir os riscos; 
- Reduzir o uso de insumos externos;

- Buscar novas relações de mercado e organização social.

De acordo com Schneider (2003) o pensamento agroecológico resgata a figura do camponês e valoriza seus conhecimentos, sobretudo em relação ao convívio com o meio ambiente, aprendido através de gerações de interação do homem com os recursos naturais. O desenvolvimento rural, sob essa ótica, representa uma tentativa de ir além da modernização técnico-produtiva, apresentando-se como uma estratégia de sobrevivência das unidades familiares que buscam sua reprodução. O modelo não é mais o do agricultor-empresário, mas o do agricultor-camponês que domina tecnologias toma decisões sobre o modo de produzir e trabalhar Contudo, a agroecologia não está pensando numa agricultura apenas de subsistência, mas a integração ao mercado de produtos e insumos deve ser olhada com cautela, para não aumentar a dependência do produtor. Por outro lado, tem que reconhecer que os autores que enfatizam a necessidade de modernizar a agricultura familiar, também não deixam de reconhecer os impactos ambientais e sociais que muitas das chamadas técnicas modernas tem provocado ou poderão vir a provocar.

De acordo com Caporal (2001), há consenso sobre a necessidade de construir uma agricultura mais sustentável que considere os aspectos sociais e ambientais, além dos aspectos econômicos, e sobre a importância dos agricultores familiares na construção desse novo modelo, mas ainda há divergências sobre os modelos mais apropriados para que a agricultura familiar atinja esses objetivos. Há uma linha que defende maior competitividade e integração nos mercados e o enfoque agroecológico que se fundamenta numa profunda mudança no modelo tecnológico, na organização da produção e até mesmo numa mudança de valores e na própria organização da sociedade.

Segundo o mesmo autor, na década de 1980, foi valorizada a intensificação da mecanização no campo em detrimento das ideias em defesa da pequena produção, da reforma agrária ou de desconcentração da terra. Mesmo sabendo que a pequena produção faz um uso mais intensivo dos fatores à sua disposição, aproveita uma maior parcela de sua terra, emprega mais mão-de-obra e tem uma produção por hectare maior do que os latifúndios. No entanto esse cenário explora mais a mão-de-obra família, não denotando um fator social positivo, mas explica a continuidade dessas propriedades em todos os setores. Porém o crescimento da produção e da produtividade na agricultura não deve ser considerado somente no setor econômico, mas também no social, pois se sabe 
que os benefícios derivados desse crescimento não são repassados para a sociedade como um todo.

Para considerar o crescimento social juntamente com a econômica é necessária a compreensão da agricultura brasileira como parte do desenvolvimento do modo de produção capitalista, um desenvolvimento contraditório e combinado que ao mesmo tempo em que produz as relações capitalistas de produção também reproduz as relação não capitalistas de produção (agricultura familiar). (OLIVEIRA, 2001)

Motuca (SP) será a primeira cidade a ter uma usina de biodiesel da agricultura familiar. A Usina terá capacidade de produzir seis milhões de litros de combustível por ano. A matéria-prima, que será soja e crambe, será fornecida por de cerca de dois mil produtores da região, através de uma cooperativa (LUIZ, 2014) .

\subsection{Avaliação econômica de projetos de investimentos}

De acordo Gitman (2010), existem vários recursos disponíveis para auxiliar as empresas no tratamento de questões relacionadas às diversas modalidades de investimentos, inclusive nas relacionadas aos investimentos em ativo imobilizado.

Em geral, são chamados de métodos, técnicas, ferramentas ou critérios de ordenação, análise e avaliação de investimentos, de orçamentos de capital ou de projetos de investimentos. Quando envolvidas com questões relacionadas a investimentos, algumas empresas se bastam com procedimentos simples, muitos sustentados apenas na experiência acumulada por seus gestores, enquanto outras sentem a necessidade da aplicação de ferramentas mais sofisticadas e analíticas (BRUNI, 2008).

\subsubsection{Valor Presente Líquido}

Segundo Samanez (2009), o método do valor presente líquido

(VPL) tem como finalidade calcular, em termos de valor presente, o impacto dos eventos futuros associados a uma alternativa de investimento. Em outras palavras, ele mede o valor presente dos fluxos de caixa gerados pelo projeto ao longo de sua vida útil. Se não houver restrição de capital, argumenta-se que esse critério leva à escolha ótima, pois maximiza o valor da empresa.

De acordo com Pilão e Vampré (2003) o método do valor presente líquido permite conhecer as necessidades de caixa, ou os ganhos de certo projeto, em 
termos de dinheiro de hoje. Isso porque normalmente se considera a somatória na data zero dos valores existentes no fluxo de caixa como o seu Valor Atual, ou Valor Presente Líquido (VPL), isto é, a somatória dos valores existentes no fluxo de caixa já descontados os juros embutidos em cada um dos valores existentes nas demais datas do fluxo.

A característica essencial deste método é a análise das alternativas de ação existentes, considerando-se para efeito de comparação um valor único colocado em uma data arbitrária, normalmente a data zero, como o Valor presente $(\mathrm{P})$ equivalente a cada um dos fluxos de caixa representativos de cada uma das opções (CASAROTTO, 2010).

Se considerar, como de fato ocorre que os valores entram e saem dos fluxos de caixa nas mais diversas datas, em função de cada negócio específico, novamente estaremos tratando aqui da necessidade do deslocamento do dinheiro no tempo, no caso, para a data 0 do fluxo. Portanto, para podermos proceder à somatória dos diversos fluxos na data 0 , teremos que deslocar o dinheiro no tempo, sendo que para isso, novamente, faremos uso da Taxa Mínima de Atratividade (TMA) (HIRSCHFELD, 2007).

Pelo Método do Valor Presente Líquido poderemos obter como resultado da somatória desses fluxos um valor atual positivo $(+)$, um valor atual negativo (-) ou um valor atual nulo (0), evidentemente que desde que tenhamos envolvidas no negócio receitas e despesas, entradas (+) e saídas (-) de caixa. Em termos de análise serão consideradas interessantes as alternativas de ação cujos valores atuais sejam positivos ou nulos, sendo tanto mais interessante quanto maior for o valor atual positivo isso porque o valor positivo representará a quantidade de dinheiro que teremos ganho, em dinheiro de hoje, além da expectativa. (BRUNI, 2008).

Batalha (2009) define que um resultado do valor atual negativo para um fluxo de caixa que tenha receitas e despesas envolvidas significará que aquele negócio possui uma remuneração aquém da expectativa, ou, ainda, que aquele negócio paga aquela quantidade de dinheiro, em dinheiro de hoje a menos do que gostaríamos, enquanto um resultado nulo para a somatória dos valores na data 0 demonstrará que aquele investimento paga exatamente a Taxa Mínima de Atratividade (TMA), portanto, também poderá ser considerado um investimento interessante.

É evidente que se utilizarmos este método para analisarmos projetos que envolvam apenas custos, o que normalmente ocorre em função da obrigatoriedade de sua implantação, ou mesmo em função de que as receitas para todas as 
alternativas de ação sejam exatamente as mesmas não influenciando, dessa forma, a escolha do melhor investimento, as alternativas de ação que nos interessarão serão aquelas que nos levarem mais próximo de um custo zero (PILÃO e VAMPRÉ, 2003).

\subsubsection{Taxa Interna de Retorno (TIR)}

O método da taxa interna de retorno (TIR) não tem como finalidade a avaliação absoluta a determinado custo de capital (processo de atualização), como o valor presente líquido (VPL); objetiva encontrar uma taxa intrínseca de rendimento. Por definição, a taxa interna de retorno é a taxa de retorno do investimento, matematicamente, a taxa interna de retorno é uma taxa hipotética que anula o valor presente líquido (BATALHA, 2009) .

De acordo com Casarotto (2010), a regra decisória a ser seguida no método da taxa interna de retorno é: empreenda o projeto de investimento se a taxa interna de atratividade exceder o custo de oportunidade de capital. Essencialmente, o método pergunta: A taxa de retorno esperada sobre projeto de investimento excede a taxa de retorno requerida? O projeto criará valor? A princípio, parece a mesma coisa que a regra do valor presente líquido, mas isso nem sempre é verdadeiro. $\mathrm{O}$ apelo intuitivo do método da taxa interna de retorno, provavelmente, responde por seu uso generalizado; as pessoas em geral, tendem a tomar decisões fazendo comparações em termos de porcentagens.

De acordo com Samanez (2009) a Taxa Interna de Retorno de um investimento pode ser conforme descritos a seguir:

- Taxa Interna de Retorno maior do que a taxa minima de atratividade, significa que o investimento é economicamente atrativo. TIR $>$ TMA $=$ VPL $(+)$.

- Taxa Interna de Retorno igual à taxa mínima de atratividade, o investimento está economicamente numa situação de indiferença. TIR=TMA = VPL (0).

- Taxa interna de retorno menor do que a taxa mínima de atratividade, o investimento não é economicamente atrativo, pois seu retorno é superado pelo retorno de um investimento com o mínimo de retorno. TIR $<$ TMA $=$ VPL (-).

Segundo Pilão e Vampré (2003), entre vários investimentos, o melhor será aquele que tiver a maior Taxa Interna de Retorno, a Taxa Interna de Retorno é a taxa de juros que torna o valor presente das entradas de caixa igual ao valor presente das saídas de caixa do investimento, para o cálculo da Taxa Interna de Retorno (TIR) é 
necessario projetar um fluxo de caixa que aponte as entradas e saidas de dinheiro provocadas pelo investimento, os compnentes são:

- O programa de investimentos ( capital fixo mais capital de giro).

- Capital e o custo de capital utilizado para realizar o investimento.

- Benefícios estimados do investimento (receita menos gasto do projeto).

- Vida útil do projeto (geralmente espressa em numero de anos).

- O valor residual do investimento ao término da vida útil do projeto.

\subsubsection{Payback descontado}

Segundo Samanez (2009), muitas vezes precisamos saber o tempo de recuperação de um investimento, ou seja, quantos anos decorrerão até que o valor presente dos fluxos de caixa previstos se iguale ao investimento inicial.

Este método é aplicado de duas formas: payback simples e payback descontado. A principal diferença entre os dois é que o payback descontado considera o valor temporal do dinheiro, ou seja, atualiza os fluxos futuros de caixa a uma taxa de aplicação no mercado financeiro, trazendo os fluxos a valor presente, para depois calcular o período de recuperação (PILÃO e VAMPRÉ, 2003).

É imprudente considerar este método como decisão de investimento, pois não contempla os fluxos de caixa após o período de recuperação. Este método pode levar a escolha de um projeto que tenha um prazo de retorno muito baixo, desconsiderando outro com período mais longo, mas que possa gerar maior riqueza para o proprietário, ou seja, que apresente um VPL maior (CASAROTTO, 2010).

Se um determinado investimento apresenta um fluxo anual maior no início implicará em um período mais curto de recuperação, mas pode ser apenas um payback ilusório se depois deste período apresentar fluxos negativos, por exemplo. Além disso, este período de recuperação normalmente é definido de forma arbitrária pelo administrador (BATALHA, 2009).

Sendo ao mesmo tempo de fácil identificação e interpretação, porém com deficiências graves para decisões de longo prazo, este método é comumente usado pelas empresas para decisões que representem menor impacto e, portanto, com características menos importantes, relativas a pequenos procedimentos gerenciais 
necessários para o funcionamento do dia-a-dia da empresa, com enfoque maior no controle e avaliação do desempenho dos administradores (BRUNI, 2008).

\subsubsection{Custos de Produção}

De acordo com Hoffmann et al., (1984) cabe ressaltar a importância da gestão produtiva e da gestão de custos, como ferramenta de apoio na tomada de decisão, uma vez que sua utilização pode servir de base para a definição da escolha do melhor projeto entre as três miniusinas pesquisadas.

Segundo o mesmo autor a expressão custo possui vários significados sendo que, para fins de analise economica, definem como a compensação que os donos dos fatores, utilizados por uma firma para produzir determinado bem, devem receber para que eles continuem fornecendo esses fatores a mesma. $\mathrm{O}$ mesmo autor comenta que os custos podem ser classificados como fixos e variáveis. São fixos, os custos que não variam com as quantidades produzidas, e variáveis, os custos que se alteram de acordo com o nível de produção da empresa.

\subsubsection{Custos Fixos}

Custos fixos são aqueles que não estão ligados as decisões de curto prazo sobre a produção a ser realizada; são também chamados de custos inevitáveis, já que o agricultor arca com os mesmos executando, ou não, o processo produtivo (FILHO; GONZAGA, 1991).

Turra (1990), trabalhando com uma analise de diferentes métodos de cálculos de custos de produção na agricultura brasileira, afirma que podem ser considerados custos fixos a depreciação, os seguros, taxas, impostos e os juros sobre os fatores fixos de produção como, capital investido em terras e em outros ativos fixos.

\subsubsection{Depreciação}

A depreciação é o custo necessário para substituir os bens de capital de longa duração, quando estes se tornam inutilizáveis em decorrência do desgaste 
físico e perdem valor com o passar dos anos devido às inovações tecnológicas e, ou, a capacidade de gerar receitas (HIRSCHFELD, 2007 e MATHIAS, 2009).

\subsubsection{Custos Variáveis}

Os custos operacionais e de manutenção (custos variáveis) compreendem, fundamentalmente, os dispêndios realizados com mão-de-obra, reparos dos equipamentos e infraestrutura utilizada na operação do sistema de secagem, além da energia, em seu trabalho de analise de custos de produção da agricultura brasileira, dispõe que podem ser considerados como variáveis as despesas com equipamentos (energia e manutenção), implementos, animais de trabalho, manutenção das benfeitorias, mão-deobra temporária, insumos, transporte externo, assistência técnica, custos financeiros e despesas gerais (SANVICENTE, 1998).

A revisão da literatura abordada permitiu o desenvolvimento desta dissertação apresentando conhecimentos técnicos do processo de produção de biodiesel e seus subprodutos, ferramentas de análise econômica - financeira e inclusão social através da agricultura familiar. 


\section{MATERIAL E MÉTODOS}

Este trabalho utilizou os valores referentes ao custo do óleo da cultura de Crambe (Crambe abyssinica Hochst) como matéria prima para produção de biodiesel, a definição do tipo de miniusina a ser utilizada e a edificação para comportar todo este processo.

\subsection{Material}

a) Custo do óleo da cultura de Crambe (Crambe abyssinica Hochst) como matéria prima para produção de biodiesel;

b) A definição do tipo de miniusina a ser utilizada;

c) A edificação para comportar todo este processo.

\subsection{Métodos}

A metodologia adotada neste trabalho foi avaliar os indicadores de viabilidade econômica, os investimentos, os custos de produção, suas receitas e custos mensais determinar a viabilidade econômica de três miniusinas para a produção de biodiesel. 


\subsubsection{Indicadores de viabilidade econômica}

Neste trabalho foram utilizados os principais métodos para auxiliar na avaliação de propostas de dispêndio de capital: o valor presente líquido (VPL); a taxa interna de retorno (TIR), o período de payback descontado e a depreciação pelo linear (MATARAZZO, 1998).

De acordo com Bruni (2008), para o cálculo da taxa mínima de atratividade (TMA) considera-se ao menos à remuneração aceitável do mercado financeiro, portanto utilizou-se o índice de $11 \%$ ao ano correspondente a $0,8735 \%$ ao mês, referente à taxa que remunera os títulos públicos do Serviço Especial de Liquidação e Custódia dos Títulos Públicos - SELIC (BANCO CENTRAL DO BRASIL,2014).

a) Valor Presente Líquido (VPL): de acordo com Samanez (2009), o valor presente líquido tem como finalidade calcular, em termos de valor presente, o impacto dos eventos futuros associados a uma alternativa de investimento. Em outras palavras, ele mede o valor presente dos fluxos de caixa gerados pelo projeto ao longo de sua vida útil. Se não houver restrição de capital, argumenta-se que esse critério leva à escolha ótima, pois maximiza o valor da empresa. A seguinte expressão define o VPL conforme equação 1 .

$$
V P L=-I+\sum_{t=0}^{n} \frac{F C_{t}}{(1+K)^{t}}
$$

$\mathrm{FC}_{\mathrm{t}}$ - representa o fluxo de caixa no t-ésimo período.

I - investimento Inicial.

K - custo de capital.

$\Sigma$ - somatório.

t - contador de tempo.

$\mathrm{n}$ - período de vida útil do investimento em anos

b) Método da Taxa Interna de Retorno (TIR): não tem finalidade a avaliação da rentabilidade absoluta a determinado custo de capital (processo de 
atualização), como o VPL; mas objetiva encontrar uma taxa intrínseca de rendimento. Por definição, a TIR é a taxa de retorno do investimento, esta taxa corresponde aquela em que o VPL é igual a zero (MATHIAS, 2009).

Segundo Silva (2006), o conhecimento da taxa interna de retorno dos investimentos de interesse da empresa possibilita o posicionamento e decisão acerca de uma série de questões em particular, como, por exemplo, comparar e decidir entre diferentes oportunidades de investimentos realizados, estando representada na equação 2 .

$$
V P L=-I+\sum_{t=1}^{n} \frac{F C_{t}}{(1+i)^{t}}=0
$$

$\mathrm{FC}_{\mathrm{t}}$ - representa o fluxo de caixa no t-ésimo período.

I - investimento Inicial.

i - taxa interna de retorno.

$\Sigma$ - somatório.

t - contador de tempo.

n - período de vida útil do investimento em anos.

c) Método do prazo de recuperação de capital (payback descontado): segundo Ross (2007), é definido como o número de períodos necessários para que o somatório dos fluxos de caixa futuros descontados à taxa mínima de atratividade se iguale ao investimento inicial, definida na equação 3.

$$
I=\sum_{t=1}^{T} \frac{F C_{t}}{(1+i)^{t}}
$$

$\mathrm{FC}_{\mathrm{t}}$ - representa o fluxo de caixa no t-ésimo período.

I - investimento Inicial.

i - taxa mínima de atratividade.

$\Sigma$ - somatório. 
$\mathrm{t}$ - contador de tempo.

$\mathrm{T}$ - payback descontado.

Por meio dos indicadores econômicos utilizados neste trabalho, foi possível determinar a avaliação da viabilidade econômica de três miniusinas para a produção de biodiesel com capacidades de (44, 66 e 110 litros por batelada) utilizando-se a semente de crambe (Crambe abyssinica Hochst) como matéria prima para produção de biodiesel. Para o estudo, considerou-se uma vida útil de 60 meses para as miniusinas que é o tempo utilizado para este tipo de investimento (COSTA, 2009).

Para realizar o cálculo da depreciação: de acordo com Receita Federal (2014), máquinas e equipamentos os bens sofrem uma depreciação de $10 \%$ ao ano durante 10 anos, ou seja, 120 meses e os Imóveis se depreciam $4 \%$ ao ano durante 25 anos, ou seja, 300 meses,

Os impostos considerados por litro de biodiesel, quando este for produzido a partir da matéria-prima de origem da agricultura familiar agregam em R\$ 0,07 por litro (IEA, 2014).

Para a realização da viabilidade econômica do projeto considerouse que a produção das miniusina de 44, 66 e 110 litros devem ser de 6 bateladas diárias, sendo que a cada 1h20min produz uma batelada totalizando 8 horas trabalhadas ao dia e o processo de decantação dura em média $12 \mathrm{~h}$.

\subsubsection{Investimentos}

$\mathrm{Na}$ categoria máquinas e equipamentos, fez-se a escolha considerando o modelo apresentado nas características técnicas que são as mais adequadas às necessidades do projeto de uma miniusina, como: capacidade de produção; manutenção; prazo de entrega; assistência técnica; tecnologia eficiente e fácil de operar; e, por fim, o melhor preço do equipamento em relação a outros fornecedores (DE LORENZO, 2014).

Na Tabela 6, são a presentados os dados que influenciaram na escolha das miniusinas. 
Tabela 6 - Dados técnicos das minusinas.

\begin{tabular}{lcccc}
\hline Descriminação & Unidades & \multicolumn{3}{c}{ Capacidade das Miniusinas } \\
\hline & & 44 litros & 66 litros & 110 litros \\
Produção Mensal & $\mathrm{L}$ & 5.280 & 7.920 & 13.200 \\
Área de Plantio & ha & 10 & 15 & 24 \\
Quantidade de Sementes & $\mathrm{Kg}$ & 15.000 & 22.000 & 36.000 \\
\hline
\end{tabular}

A dimensão da edificação das miniusinas, de $64 \mathrm{~m}^{2}$, foi calculada a partir do estudo do layout dos equipamentos necessários à sua operacionalização; sendo o padrão construtivo considerado como rústico, sem forro, fechado em duas laterais, sem esquadrias, pintura, com instalações elétricas e hidráulicas simples e enquadram-se no uso de construção industrial como galpão de uso geral médio, obtendo-se o valor do metro quadrado de construção a partir de tabelas publicadas em revistas especializadas (GUIA DA CONSTRUÇÃO, 2014).

\subsubsection{Custos de produção}

As informações referentes ao custo do óleo de crambe foram obtidas a partir de Jasper et al, (2010). Os autores apresentaram os resultados do custo médio por hectare das operações mecanizadas e insumos envolvidos desde a dessecação da área até a colheita do Crambe abyssinica Hochst e seu processamento (pós-colheita). Os dados foram atualizados até o ano de 2013 pelo IGP-M - índice geral de preços do mercado (fator de 1,30809\% para o acumulado) da FGV - Fundação Getúlio Vargas, (PORTAL BRASIL, 2014).

Na Tabela 7, constam os dados utilizados para o cálculo do custo do óleo de crambe conforme Jasper et al. (2010) atualizado monetariamente até o ano de 2013 pela variação IGP-M./FGV. 
Tabela 7 - Custo do óleo de crambe.

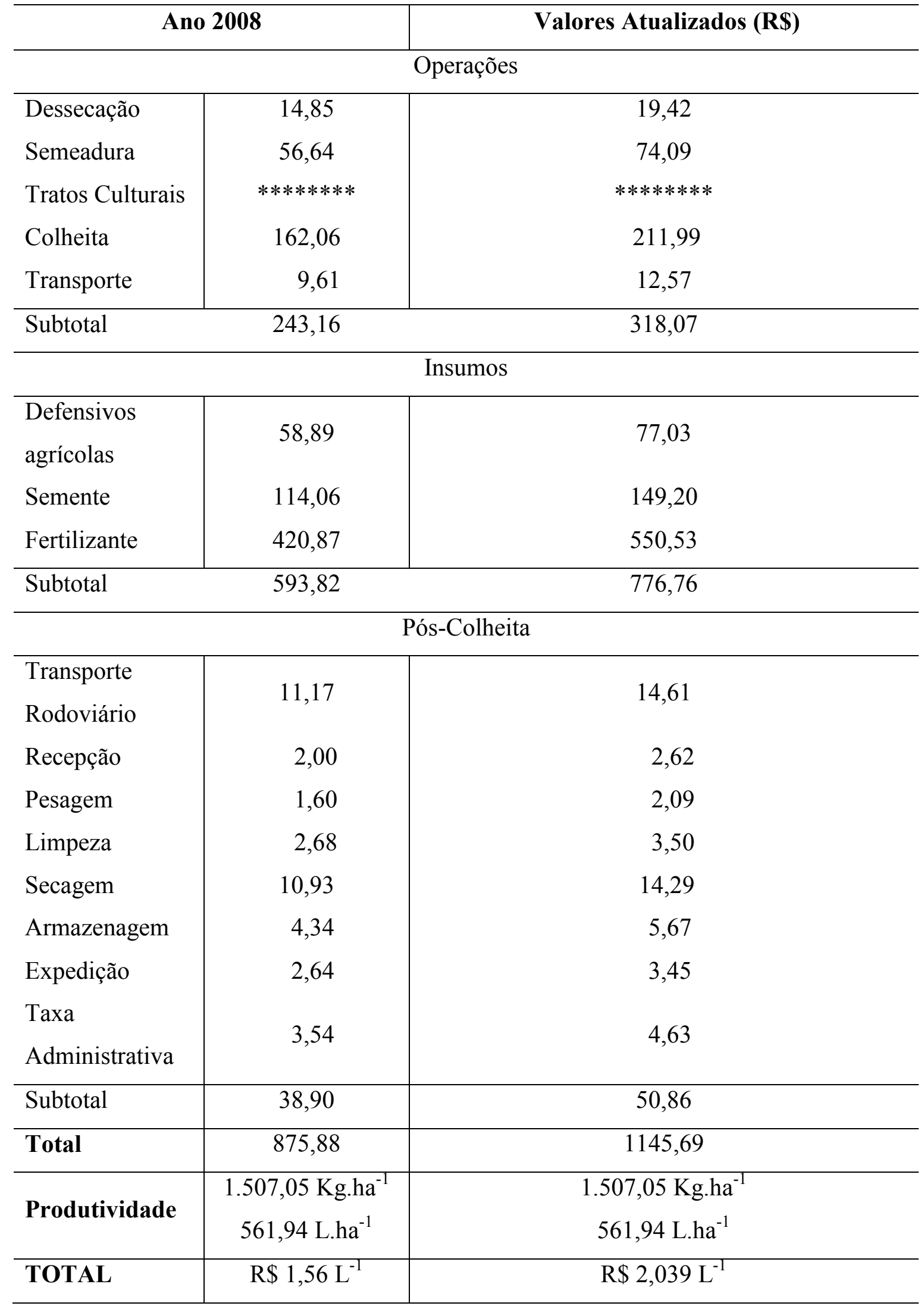

Crambe abyssinica Hoschst - Teor de óleo de 37,29\%.

Fonte: Jasper et a., 2010, adaptado. 


\subsubsection{Receitas mensais}

Para o cálculo das receitas mensais foram utilizados os seguintes dados considerados: 1 litro de óleo de crambe utiliza 2,682 $\mathrm{Kg}$ de semente de crambe e resulta em torta de crambe $1,682 \mathrm{Kg}$ e corresponde a teor de óleo $(37,29 \%)$ e torta de crambe $(62,72 \%), 1$ litro de biodiesel pago pelos leilões (quantidade 20 leilões) preço médio é de $\mathrm{R} \$ 2,2299,1 \mathrm{Kg}$ de torta de crambe pago pelas empresas preço médio é de $\mathrm{R} \$$ 0,5129, 1 litro de glicerol sendo que preço médio pago pelas empresas é de R 0,6020.

\subsubsection{Custos Mensais}

Para o cálculo dos custos mensais foram utilizados os seguintes dados considerados: 1 litro de óleo de crambe custa $\mathrm{R} \$ 2,0389$, 1 litro de metanol custa $\mathrm{R} \$$ 0,9198, $1 \mathrm{Kg}$ de hidróxido de sódio custa $\mathrm{R} \$ 12,00$, energia elétrica $700 \mathrm{~W} / \mathrm{h}$ por hora - $1 \mathrm{~kW} / \mathrm{h}$ custa $\mathrm{R} \$$ 0,3815, mão de obra conforme os dados do Instituto de Economia Agrícola 04/04/2014 - para um funcionário mensalista custa: R\$ 1.250,00, mais impostos de 1,62 , seu custo total é de $\mathrm{R} \$ 2.025,00$. 


\section{RESULTADOS E DISCUSSÃO}

\subsection{Investimento inicial}

O cultivo de matérias-primas e a produção de biodiesel têm grande potencial de inclusão social, especialmente quando se considera o amplo potencial produtivo da agricultura familiar, sendo assim, este trabalho apresenta uma alternativa de geração de renda, uma vez que estuda a viabilidade econômica de três miniusinas para produção de biodiesel utilizando a semente de crambe (Crambe abyssinica Hochst) como matéria prima.

Para a determinação de investimentos de acordo com a Tabela 8 são apresentados os aportes necessários para colocar as miniusinas em funcionamento, como máquinas e equipamentos e instalações para as miniusinas de 44, 66 e 110 litros e os cálculos estão detalhados no apêndice 1 .

$\mathrm{Na}$ Tabela 8 constam as despesas de investimentos em instalações. 
Tabela 8 - Despesa de investimento em instalações para miniusinas de biodiesel com capacidade de 44, 66 e 110 litros.

\begin{tabular}{lrrr}
\hline Categoria & \multicolumn{3}{c}{ Valores (R\$) } \\
\hline & Miniusina de & Miniusina de & Miniusina de \\
& 44 litros & 66 litros & 110 litros \\
Máquinas/equipamentos & $108.500,00$ & $116.700,00$ & $126.000,00$ \\
Instalações & $30.232,00$ & $30.232,00$ & $30.232,32$ \\
\hline Total Geral & $138.732,32$ & $146.932,32$ & $156.232,32$ \\
\hline
\end{tabular}

\subsection{Custo mensal}

Para obtenção dos custos mensais de acordo com as Tabelas 9, 10 e 11, são apresentados os custos obtidos sem impostos que são desembolsáveis pelo projeto mensalmente e contemplam os cenários para as miniusinas de 44, 66 e 110 litros. Todos os demais custos envolvidos no processo de produção: óleo de crambe, metanol, hidróxido de sódio, energia elétrica, mão de obra, depreciação, impostos e limpeza, foram calculados baseados na produção mensal de cada miniusina e os cálculos estão detalhados nos apêndices 5, 6 e 7.

Tabela 9 - Custos mensais para miniusina de biodiesel com capacidade de 44 litros produzindo 5280 litros / mês.

\begin{tabular}{lcccr}
\hline Descrição & Unidades & Valores (R\$) & Quantidade & Valor Total (R\$) \\
\hline Óleo de crambe & $\mathrm{L}$ & 2,0389 & 5.280 & $10.765,39$ \\
Metanol & $\mathrm{L}$ & 0,9198 & 475.2 & 437,09 \\
Hidróxido de sódio & $\mathrm{Kg}$ & 0,1200 & 5.280 & 633,60 \\
Limpeza & $\mathrm{L}$ & 249,9000 & 1 & 249,90 \\
Energia elétrica & $\mathrm{kWh} / \mathrm{mês}$ & 0,3815 & 123.2 & 47,00 \\
Mão-de-obra & $\mathrm{N}$ ( Func. & $2.025,0000$ & 1 & $2.025,00$ \\
Depreciação & $\mathrm{R} \$$ & $1.004,9400$ & 2 & $1.004,94$ \\
\hline Total & & & & $15.162,92$ \\
\hline Custo total por litro & & &
\end{tabular}


Como se observa na Tabela 9, o maior custo do processo é o óleo de crambe $71 \%$. Os custos variáveis são de $78 \%$ dos custos totais, representados pelo óleo de crambe, o metanol e o hidróxido de sódio.

Tabela 10 - Custos mensais para miniusina de biodiesel com capacidade de 66 litros produzindo 7920 litros / mês.

\begin{tabular}{lcccr}
\hline Descrição & Unidades & Valores (R\$) & Quantidade & Valor Total (R\$) \\
\hline Óleo de crambe & $\mathrm{L}$ & 2,0389 & 7.920 & $16.148,09$ \\
Metanol & $\mathrm{L}$ & 0,9198 & 712.8 & 655,63 \\
Hidróxido de sódio & $\mathrm{Kg}$ & 0,1200 & 7.920 & 950,40 \\
Limpeza & $\mathrm{L}$ & 249,9000 & 1 & 249,90 \\
Energia elétrica & $\mathrm{kWh} / \mathrm{mês}$ & 0,3815 & 123.2 & 47,00 \\
Mão-de-obra & $\mathrm{N}$ Func. & $2.025,0000$ & 1 & $2.025,00$ \\
Depreciação & $\mathrm{R} \$$ & $1.073,2700$ & 2 & $1.073,27$ \\
\hline Total & & & & $21.149,29$ \\
\hline Custo total por litro & & & & 2,67 \\
\hline
\end{tabular}

$\mathrm{Na}$ Tabela 10, percebe-se que as alterações no custo variável se elevam para $84 \%$ do custo total. No custo fixo a alteração do valor da depreciação se deve ao maior custo de aquisição da miniusina de 66 litros.

Tabela 11 - Custos mensais para miniusina de biodiesel capacidade 110 litros produzindo 13200 litros / mês.

\begin{tabular}{lcccr}
\hline Descrição & Unidades & Valores (R\$) & Quantidade & Valor Total (R\$) \\
\hline Óleo de crambe & $\mathrm{L}$ & 2,0389 & 13.200 & $26.913,48$ \\
Metanol & $\mathrm{L}$ & 0,9198 & 1188 & $1.092,72$ \\
Hidróxido de sódio & $\mathrm{Kg}$ & 0,1200 & 13.200 & $1.584,00$ \\
Limpeza & $\mathrm{L}$ & 249,9000 & 1 & 249,90 \\
Energia elétrica & $\mathrm{kWh} / \mathrm{mês}$ & 0,3815 & 123.2 & 47,00 \\
Mão-de-obra & $\mathrm{N}$ Func. & $2.025,0000$ & 1 & $2.025,00$ \\
Depreciação & $\mathrm{R} \$$ & $1.150,7700$ & 2 & $1.550,77$ \\
\hline Total & & & & $33.062,87$ \\
\hline Custo total por litro & & & & 2,50 \\
\hline
\end{tabular}


$\mathrm{Na}$ Tabela 11, verifica-se que as alterações no custo variável se elevam para $89 \%$ do custo total. No custo fixo a alteração do valor da depreciação se deve ao maior custo de aquisição da miniusina de 110 litros, contudo a edificação de $64 \mathrm{~m}^{2}$ é suficiente para os três tamanho de miniusina, o que otimiza este item.

Os custos operacionais das miniusinas são representados em sua maior parte pelos custos variáveis, sobretudo da matéria prima que é o óleo de crambe. Os custos fixos sofreram alterações apenas na depreciação de equipamentos, pois as diferenças de valores de aquisição impactaram sobre este item. As diferenças de custos por unidade produzida se referem à diluição do custo fixo pelo volume de produção. Enquanto o custo variável unitário não se alterou, o custo fixo unitário foi decrescente.

Percebe-se que a redução de custo de produção total ocorrerá com um menor custo de aquisição do óleo de crambe, sobretudo na produção de semente.

Segundo Carlos Pitol, Engenheiro Agrônomo e Pesquisador da Fundação MS, o bom desempenho do crambe nos campos experimentais localizados na região Sul do Estado do Mato Grosso do Sul, nos municípios de Mundo Novo, Itaquirai, Eldorado, Iguatemi e Japorã se deve ao baixo custo de produção, rusticidade, adaptabilidade fácil a solos eutróficos, resistência à seca, não exige novas máquinas e equipamentos para o seu cultivo e a facilidade de extração do óleo através de prensa/extrusora. Os custos de produção variam entre $\mathrm{R} \$ 250,00$ e $\mathrm{R} \$ 300,00$ por hectare, com estimativas de produção em torno de 1,5 toneladas por hectare. Os dados obtidos com as análises feitas no laboratório da Universidade para o Desenvolvimento do Estado e da Região do Pantanal (UNIDERP) indicam produção média de $38 \%$ de teor total de óleo, podendo variar este índice, de acordo com as condições de clima e solo (BIODIESEL 2014).

De acordo com Jasper et al. (2010), no ano de 2008 na Fazenda Experimental Lageado, pertencente à Faculdade de Ciências Agronômicas UNESP ( Universidade Estadual Paulista), localizada no município de Botucatu - SP, os custos de produção do crambe variam na média de $\mathrm{R} \$ 875,00$ por hectare, com estimativas de produção de 1,5 toneladas por hectare e teor de óleo em média de 37 \% .

Outra opção para reduzir o custo fixo unitário poderia ser estudar um aumento na utilização da capacidade instalada aumentando a produção de bateladas por dia de produção tendo como consequência um aumento na quantidade total produzida sem 
um aumento proporcional nos custos de produção gerando uma economia de escala de produção.

\subsection{Receita mensal}

Para a obtenção das receitas oriundas do biodiesel, glicerol e torta de crambe obtidas em cada miniusina, conforme Tabelas 12, 13 e 14 são apresentadas as receitas obtidas mensalmente pelo projeto as quais contemplam os cenários para as miniusinas de 44, 66 e 110 litros e os cálculos estão detalhados nos apêndices 2, 3 e 4 .

Tabela 12 - Receitas de venda mensal para miniusina de biodiesel com capacidade de 44 litros produzindo 5280 litros / mês.

\begin{tabular}{lcccr}
\hline Descrição & Unidades & Valores (R\$) & Quantidade & Valor Total (R\$) \\
\hline Biodiesel & $\mathrm{L}$ & 2,2299 & 5.280 & $11.773,87$ \\
Glicerol & $\mathrm{L}$ & 0,6020 & 528 & 317,86 \\
Torta de crambe & $\mathrm{Kg}$ & 0,5129 & $8.880,96$ & $4.555,04$ \\
\hline Total & & & & $16.647,77$ \\
\hline
\end{tabular}

Tabela 13 - Receitas de venda mensal para miniusina de biodiesel com capacidade de 66 litros produzindo 13200 litros / mês.

\begin{tabular}{lcccr}
\hline Descrição & Unidades & Valores (R\$) & Quantidade & Valor Total (R\$) \\
\hline Biodiesel & $\mathrm{L}$ & 2,2299 & 7.920 & $17.660,81$ \\
Glicerol & $\mathrm{L}$ & 0,6020 & 792 & 476,78 \\
Torta de crambe & $\mathrm{Kg}$ & 0,5129 & $13.321,44$ & $6.832,57$ \\
\hline Total & & & & $24.970,16$ \\
\hline
\end{tabular}

Tabela 14 - Receitas de venda mensal para miniusina de biodiesel com capacidade de 66 litros produzindo 7920 litros / mês.

\begin{tabular}{lcccr}
\hline Descrição & Unidades & Valores (R\$) & Quantidade & Valor Total (R\$) \\
\hline Biodiesel & $\mathrm{L}$ & 2,2299 & 13.200 & $29.434,68$ \\
Glicerol & $\mathrm{L}$ & 0,6020 & 1.320 & 794,64 \\
Torta de crambe & $\mathrm{Kg}$ & 0,5129 & $22.202,24$ & $11.387,53$ \\
\hline Total & & & & $41.616,85$ \\
\hline
\end{tabular}


As receitas das miniusinas foram proporcionais a sua capacidade de produção sendo que o biodiesel representou $70,7 \%$ da receita, o glicerol 1,9\%, e a torta de crambe $27,3 \%$.

\subsection{Análise econômica}

Nas Tabelas 15 e 16 são demonstradas as análises de viabilidade econômica sem impostos e com impostos para instalação de miniusina de biodiesel e contemplam os cenários para as miniusinas de 44, 66 e 110 litros.

Tabela 15 - Resultado econômico e análise da viabilidade sem impostos.

\begin{tabular}{lrrr}
\hline \multicolumn{1}{c}{ Descrição } & \multicolumn{3}{c}{ Valores (R\$) } \\
\hline & Miniusina & Miniusina & Miniusina \\
& 44 litros & 66 litros & 110 litros \\
& Sem Impostos & Sem Impostos & Sem Impostos \\
Receitas mensais (R\$) & $16.646,77$ & $24.970,16$ & $41.616,85$ \\
Custos mensais (R\$) & $15.162,92$ & $21.149,29$ & $33.062,87$ \\
Resultado (R\$) & $1.483,85$ & $3.820,87$ & $8.553,98$ \\
Depreciação (R\$) & $1.004,94$ & $1.073,27$ & $1.150,77$ \\
Fluxo caixa (saldo R\$) & $2.488,79$ & $4.894,14$ & $9.704,75$ \\
Investimento (R\$) & $-138.732,32$ & $-146.932,32$ & $-156.232,32$ \\
VPL (60 meses) & $-22.892,44$ & $80.863,58$ & $295.471,74$ \\
Payback descontado (meses) & 77 & 35 & 18 \\
TIR 60 meses (mensal) & $0,2445 \%$ & $2,63 \%$ & $6,03 \%$ \\
\hline
\end{tabular}

Na Tabela 15 para a miniusina com capacidade de produção de 44 litros a análise da viabilidade econômica sem impostos mostrou que: o valor presente líquido (VPL) foi negativo em $\mathrm{R}$ \$ 22.892,44, significando que para um horizonte de 60 meses a miniusina terá um custo superior às receitas representado pelo VPL e para a miniusina se pagar seriam necessários 77 meses de operação para o pagamento do investimento. Desta forma o produtor somente começaria a ter retorno após os 77 meses. A taxa interna de retorno (TIR) demonstra que a viabilidade em 60 meses ocorre a uma taxa mensal de 0,2445\%, bastante inferior à taxa mínima de atratividade que é de $0,8735 \%$ ao mês, ou seja, mantendo o horizonte de 60 meses. 
Para a miniusina com capacidade de produção de 66 litros a análise da viabilidade econômica sem impostos, apresenta o valor presente líquido (VPL) positivo de $\mathrm{R} \$ 80.863,58$, mostrando que para a miniusina se pagar seriam necessários 35 meses. A taxa interna de retorno (TIR) demonstra que a viabilidade em 60 meses ocorre a uma taxa mensal de 2,63\%, bastante superior à taxa mínima de atratividade que é de $0,8735 \%$ ao mês.

Para a miniusina com capacidade de produção de 110 litros a análise da viabilidade econômica sem impostos mostrou que o valor presente líquido (VPL) foi positivo em $\mathrm{R} \$ 295.471,74$ e para a miniusina se pagar seriam necessários 18 meses. A taxa interna de retorno (TIR) demonstra que a viabilidade em 60 meses ocorre a uma taxa mensal de 6,03\%, bastante superior à taxa mínima de atratividade que é de $0,8735 \%$ ao mês.

Tabela 16 - Análise da viabilidade econômica com impostos.

\begin{tabular}{lrrr}
\hline \multicolumn{1}{c}{ Descrição } & Miniusina & Miniusina & Miniusina \\
& 44 litros & 66 litros & 110 litros \\
& Com Impostos & Com Impostos & Com Impostos \\
Receitas mensais (R\$) & $16.646,77$ & $24.970,16$ & $41.616,85$ \\
Custos mensais (R\$) & $15.532,52$ & $21.703,69$ & $33.986,87$ \\
Resultado (R\$) & $1.114,25$ & $3.266,47$ & $7.629,98$ \\
Depreciação (R\$) & $1.004,94$ & $1.073,27$ & $1.150,77$ \\
Fluxo caixa (saldo R\$) & $2.119,19$ & $4.339,74$ & $8.780,75$ \\
Investimento (R\$) & $-138.732,32$ & $-146.932,32$ & $-156.232,32$ \\
VPL (60 meses) & $-40.095,32$ & $55.059,22$ & $252.464,48$ \\
Payback descontado (meses) & 98 & 41 & 20 \\
TIR 60 meses (mensal) & $-0,2815 \%$ & $2,11 \%$ & $5,38 \%$ \\
\hline
\end{tabular}

Analisando a viabilidade econômica da miniusina com capacidade de produção de 44 litros com impostos (Tabela 16) verifica-se que: o valor presente líquido (VPL) foi negativo em $\mathrm{R} \$ 40.095,32$, mostrando que para a miniusina se pagar seriam necessários 98 meses, um prazo excessivamente longo para este montante de investimento e para a durabilidade dos equipamentos A taxa interna de retorno (TIR) demonstra que a viabilidade em 60 meses ocorre a uma taxa mensal de $0,2815 \%$. Neste caso a taxa interna 
de retorno é negativa, ou seja, a operação funcionaria apenas com subsídio. Desta forma o investimento a ser realizado para a miniusina com capacidade de 44 litros torna-se inviável.

Analisando a miniusina com capacidade de produção de 66 litros com impostos a viabilidade econômica apresenta os seguintes: o valor presente líquido (VPL) positivo de R \$55.059,22 e para a miniusina se pagar seriam necessários 41 meses. A taxa interna de retorno (TIR) demonstra que a viabilidade em 60 meses ocorre a uma taxa mensal de $2,11 \%$, bastante superior à taxa mínima de atratividade que é de $0,8735 \%$ ao mês mesmo com o pagamento dos impostos. Desta forma o investimento a ser realizado para a miniusina com capacidade de 66 litros torna-se viável tanto para operação como para auto consumo dos produtos gerados.

Já para a miniusina com capacidade de produção de 110 litros com impostos, o valor presente líquido (VPL) foi positivo em R\$252.464,48, de modo que para a miniusina se pagar seriam necessários 20 meses. A taxa interna de retorno (TIR) demonstra que a viabilidade em 60 meses ocorre a uma taxa mensal de 5,38\%, bastante superior à taxa mínima de atratividade que é de $0,8735 \%$ ao mês. Desta forma o investimento a ser realizado para a miniusina com capacidade de 66 litros torna-se viável.

Percebe-se que os custos fixos são semelhantes independente da capacidade produtiva das miniusinas estudadas. Verifica-se que a viabilidade econômica está relacionada ao aumento das receitas como demonstrado nas miniusinas com a capacidade de 66 e 110 litros. Comparando estas miniusinas em que se demonstrou ser viável o investimento a miniusina de 110 litros apresenta alguns índices que as diferencia em relação à miniusina de 66 litros como o VPL (60 meses) aumentando em média $365 \%$, o Payback descontado (meses) diminuindo em média $94 \%$, e a TIR (mensal) aumentando em 230\%. Deve-se estudar um incremento na utilização da capacidade instalada aumentando a produção diária ou aumentando a capacidade das miniusinas sem aumentar os custos de produção gerando uma economia de escala de produção. Outra forma de aumentar as receitas é diminuir os custos de produção, potencialmente na área agrícola.

A rentabilidade com a venda da produção da semente de Crambe não é alta comparado a outras culturas, mas o cultivo oferece outras vantagens. Cobertura do solo, rotação de culturas, reciclagem de nutrientes e redução de nematóides são os principais benefícios. Outra vantagem é que a planta produz substâncias que repelem naturalmente os insetos. Além disso, não exige uso de maquinários específicos. Para o 
plantio e colheita, podem ser utilizadas as máquinas empregadas nas lavouras tradicionais como a soja e o milho, as semeadeiras são adequadas para o plantio do crambe, dada a irregularidade do tamanho das sementes da cultura (BIOMERCADO, 2014). 


\section{CONCLUSÃO}

A produção do biodiesel pode cumprir um relevante papel no fortalecimento tanto da base agroindustrial brasileira como da agricultura familiar, e agregar sustentabilidade à matriz energética nacional com redução de importações do diesel, geração de empregos e benefícios ambientais.

Conclui-se que é viável a implantação das miniusinas com capacidades de 66 e 110 litros, pois o Valor Presente Líquido (VPL) de cada empreendimento é positivo, o que significa que ao final de 60 meses, o valor do investimento será compensado pelo lucro obtido no decorrer dos períodos. Outro índice que indica a viabilidade do projeto é a Taxa Interna de Retorno (TIR) das miniusinas a qual é respectivamente de 31,56 \% e 72,36 \% ao ano, com valores superiores à Taxa Mínima de Atratividade (TMA) que para esse estudo foi considerado $11 \%$ ao ano. O tempo de retorno do investimento é de 35 meses para a miniusina de 66 litros e de 18 meses para a miniusina de 110 litros que são inferiores aos programas de financiamento para esse segmento que é de 60 meses. Verifica-se que o investimento realizado para a miniusina de 110 litros é de 7,97 \% maior em relação à miniusina de 66 litros, mas comparando-se os índices econômicos da miniusina de 110 litros o VPL é de 365,39 \% e a TIR é de 229,28 \% maiores em relação ao VPL e TIR da miniusina de 66 litros, mostrando que entre as três miniusina estudadas a de 110 litros seria o melhor investimento realizado.

Esse tipo de análise permite verificar a sustentabilidade da cadeia produtiva, analisando-se a obtenção de recursos pela Agricultura Familiar junto à indústria para pagar seus investimentos e manter suas atividades, bem como a obtenção de recursos 
para a manutenção das suas práticas agrícolas. A metodologia adotada no presente trabalho, que se propõe a apresentar uma ferramenta de auxílio à análise de viabilidade de projetos de produção de biodiesel, se extrapolada para outros cenários poderia agregar novos conteúdos e informações consubstanciando o conjunto de conhecimentos da cadeia produtiva do biodiesel. Dentre as possibilidades de estudo pode sugerir a simulação de outros cenários de produção com envolvimento de outras oleaginosas com potencial produtivo e cenários diferentes com relação à capacidade das miniusinas. 


\section{REFERÊNCIAS}

ABRAMOVAY, R. Paradigmas do capitalismo agrário em questão. São Paulo: HUCITEC/UNICAMP, 1992, 275 p.

ABDALLA. A.L. et al. Utilização de subprodutos da indústria de biodiesel na alimentação de ruminantes. 2008. Disponível em:

$<$ http://www.scielo.br/pdf/rbz/v37nspe/a30v37nsp.pdf>. Acesso em: 16 maio. 2014

ADRIA LABORATÓTIOS. Disponível em:

$<$ http://www.adrialaboratorios.com.br/4_biotec-produtos-quimicos.aspx. $>$. Acesso em: 23 abr. 2014.

ALMEIDA, J. Da ideologia do progresso à ideia de desenvolvimento (rural) sustentável. 1995. Disponível em:

$<$ http://www.ufrgs.br/pgdr/arquivos/645.pdf.>. Acesso em: $11 \mathrm{dez} .2013$.

ALTIERI, M. Agroecologia. Bases científicas para uma agricultura sustentável. Guaíba-RS: Agropecuária, 2002, 592 p.

ANP - Agência Nacional do Petróleo, gás natural e biocombustíveis. Anuário Estatístico 2001. Disponível em: <http://www.anp.gov.br/conheca/anuario_estat.asp>. Acesso em: 17 jul. 2012.

ANP , Resumo dos leilões de biodiesel da ANP de 2009 a 2013. Disponível em: $<$ http://www.anp.gov.br>. Acesso em: 21 mar..2014.

ANTONELLI, J. Cultivo do crambe: Potencial para produção de biodiesel ${ }^{1}$. Revista Brasileira de Energias Renováveis, v. 2, p. 11-22, 2012.

ARANDA, D. Biodiesel: matérias-primas, tecnologias e especificações, apresentação em "PDF" na FIESP, São Paulo, abr. 2005. 
BANCO CENRAL DO BRASIL. Disponível em: <http://www.bcb.gov.br>. Acesso em: 2 abr.2014.

BARROS,A.A.C.;WUST,E.;MEIR,H.F. Estudo da viabilidade técnico-científica da produção de biodiesel a partir de resíduos gordurosos. Engenharia Sanitária Ambiental, Rio de Janeiro, v.13,n.3 p.255-262, 2008.

BATALHA, M. O. Gestão agroindustrial. São Paulo: Atlas, 2009.

BEDUSCHI, F.; LUIZ, C.; ABRAMOVAY, R. Desafios para o desenvolvimento das regiões rurais. Nova economia, v. 14, n. 3, p. 35-70, 2004. Disponível em:

$<$ http://www.face.ufmg.br/novaeconomia/sumarios/v14n3/140302.pdf $>$. Acesso em: 11 nov. 2013.

BIANCHINI, E. 2013. Cultivo de crambe submetido a déficit hídrico. Disponível em: $<$ http://www.fag.edu.br/sis/upload/revista/cultivando_o_saber/5303887e23774.pdf > . Acesso em: 16 maio. 2014 .

BIOCOMBUSTÍVEIS A PARTIR DE ÓLEOS E GORDURAS: desafios tecnológicos para viabilizá-los. Química Nova, São Paulo, v. 32, n. 3, p. 768-775. 2009. Disponível em: $<$ http://www.scielo.br/scielo.php?script=sci_pdf\&pid=S0100$40422009000300020 \& \operatorname{lng}=\mathrm{en} \& n \mathrm{~mm}=\mathrm{iso} \& \operatorname{tn} \mathrm{l}=\mathrm{pt}>$. Acesso em: 12 out. 2013.

BIODIESEL, Disponível em : $<$ http://www.biodieselbr.com/noticias/em-foco/crambemercado-garantido-080811.htm>.. Acesso em: 28 maio. 2014.

BIOMERCADO. Agricultores colhem crambe no DF. 2014. Disponível em: $<$ http://www.biomercado.com.br/portal/not_detalhe.php?noticia=514>. Acesso em: 16 maio. 2014.

BRANDÃO, F. J. B. Desempenho operacional e produtividade agrícola do crambe nos preparos convencional e reduzido de solo. Disponível em:

$<$ http://www.conhecer.org.br/enciclop/2013b/ciencias\%20agrarias/desempenho\%20operac ional.pdf $>$. Acesso em 12 nov. 2013.

BRUNI, A. L. Avaliação de investimentos. São Paulo: Atlas, 2008.

CANOVA, H.B. Torta de crambe (Crambe Abyssinica Hochst) na alimentação de cordeiros. 2012. Disponívem em: $<$ http//www.iz.sp.gov.br/pdfs/1332337624.pdf.>. Acesso em: 16 maio. 2014.

CAPORAL, F.R.; COSTABEBER, J.A. Agroecologia e sustentabilidade. Base conceptual para uma nova Extensão Rural. In: WORLD CONGRESS OF RURAL SOCIOLOGY. 2001. p. 114-123.Disponível em:

$<$ http://scholar.google.com.br/scholar?q=CAPORAL $\% 2 \mathrm{C}+$ Francisco+Roberto $\% 3 \mathrm{~B}+\mathrm{COST}$ ABEBER $\% 2 \mathrm{C}+\mathrm{Jos} \% \mathrm{C} 3 \% \mathrm{~A} 9+\mathrm{Ant} \% \mathrm{C} 3 \% \mathrm{~B} 4$ nio. + Agroecologia $+\mathrm{e}+$ sustentabilidade.\&btnG $=\& h l=p t-B R \& a s \_s d t=0 \% 2 C 5 \& a s \_v i s=1>$. Acesso em: 10 dez. 2013. 
CARVALHO, R. Agroenergia e biocombustíveis no Brasil. Biocombustíveis em foco. Ano 1, n. 2, fev. 2009. Disponível em:

$<$ http://www.iica.org.br/Docs/Publicacoes/Agronegocio/2009/Biocombustiveis_em_FOCO -AnoI-N002.pdf $>$. Acesso em: 17 jun. 2012.

CASAROTTO, F. N.; KOPITTKE, B. H. Análise de investimentos. São Paulo: Atlas, 2010.

COSTA, F. P.; MARTINS, L. D.; LOPES, J. C. Frequência de germinação de sementes de crambe (Crambe abyssinica Hochst.) sob influência de tratamentos prégerminativos e de temperaturas. Nucleus, v. 2, n. 2, p. 1-10, 2010. Disponível em: $<$ http://dialnet.unirioja.es/servlet/articulo?codigo=4039337>. Acesso em: 12 ago. 2013.

COSTAL.G.T.A. Análise econômica financeira de empresas. FGV, 2009.,

CHÁVES, J.D.R. Aproveitamento biotecnológico do glicerol derivado da produção de biodiesel para obtenção de biomassa e ribonucleotídeos. Disponível em:

http://www.teses.usp.br/teses/disponiveis/97/97132/tde-03102012-114021/. Acesso em: 16 maio. 2014.

CPFL ENERGIA . Disponível em: <http://www.cpfl.com.br>. Acesso em: 5 maio.2014.

DEMIRBAS, A. Biodiesel fuels from vegetable oils via catalytic and non-catalytic supercritical alcohol transesterifications and other methods: a survey. Energy Conversion and Management, n.44, p. 2093 2109, 2003.

DE LORENZO DO BRASIL. Disponível em: <http://www.delorenzo.com.br>. Acesso em: 02 abr.2014.

DIESEL, R. The Diesel Oil-Engine, Engineering 93:395-406 (1912).

Chem. Abstr.6: 1984 (1912).

DABDOUB, M.J.; BRONZEL, J.L.; RAMPIN, M.A. Biodiesel: visão crítica do status e perspectivas na academia e na indústria. Quim. Nova, v.32, n³, p.776-792, 2009.

DURÃES, O. M. F. Agroenergia para biodiesel. Biocombustíveis - produção e mercado no Brasil. Passo Fundo: O Nacional, 2009.

FAO/INCRA Diretrizes de política agrária e desenvolvimento sustentável. Brasília, Versão resumida do Relatório Final do Projeto UTF/BRA/036, março, 1994.

FARMAPOINT. Embrapa estuda o crambe na alimentação de ovinos. Disponível em: http://www.farmpoint.com.br/cadeia-produtiva/giro-de-noticias/embrapa-estuda-o-crambena-alimentacao-de-ovinos-62479n.aspx. Acesso em: 16 maio. 2014

FILHO, J. P.; GONZAGA, M. L. Analise de custos de lavouras irrigadas. In: CURSOS DE AGRICULTURA IRRIGADA, 1991, Piracicaba. Anais... Piracicaba: ESALQ, 1991. p. 27-57. 
FUNDAÇÃO MS. Disponível em: < http://www.fundacaoms.org.br/produto/crambe > Acesso em: 29 maio.2014.

GITMAN, L.J. Princípios da administração financeira. 12. ed. São Paulo: Pearson, 2010.

GUIA DA CONSTRUÇÃO. Disponível em:

$<$ http://www.guiadaconstrucao.pini.com.br/cupe-sao-paulo-fev-2014/custos-unitarios-pinide-edificacoes-cupe-sao-paulo-sp-fev-2014/816>.Acesso em: 08 abr.2014.

HERCULANO, B.N. Farelo de crambe na alimentação de bovinos leiteiros. Disponível em : http://www.ufvjm.edu.br/cursos/zootecnia/index.php?option=com... Acesso em: 16 maio. 2014.

HIRSCHFELD. H. Engenharia economica. São Paulo: Atlas, 2007.

HOLANDA, Ariosto: Biodiesel e inclusão social. Brasília: Câmara dos Deputados, 2004.

HOFFMANN, R.; ENGLER, J. J. C.; THAME, A. C. M. Administração da empresa agrícola. 2a Edição. São Paulo: Pioneira, 1984. 325p.

IEA-INTERNATIONAL ENERGY AGENCY. Key world energy statistics, 2007.

Disponível em: $<$ http://www.iea.org/textbase/nppdf/free/2007/key_stats_2007.pdf $>$ Acesso em: 17 jul. 2012.

IEA - INSTITUTO DE ECONOMIA AGRÍCOLA. Disponível em:

$<$ http://www.iea.sp.gov.br>. Acesso em: 12 abr.2014.

JASPER ,S.P. et al. Comparação do custo de produção do crambe (crambe abyssinica Hochst) com outras culturas oleaginosas em sistema de plantio direto. Energia na Agricultura, Botucatu, SP , v 25, n.4, p.141-153, 2010.

JOQUIM JUNIOR, C.F. Estudo tecnológico do processo produtivo de biodiesel. Relatório de Pesquisa da Faculdade de Tecnologia de Botucatu - FATEC. 2010.

KNOTHE, G.; GERPEN, J.V.; KRAHL, J. RAMOS, L.P. Manual do

Biodiesel. São Paulo: Edgard Blucher, 2006. 340p.

LEROYMERLIN. Disponível em: <http:/www.leroymerlin.com.br/caixa-dagua-depolietileno-10001-1-40x1-69x0-79m-tigre>. Acesso em: 08 maio.2014.

LUCEMA, T.K. O Biodiesel na matriz energética brasileira. Universidade Federal do Rio de Janeiro, Instituto de Economia, 2004.

LUIZ, G.M. Motuca terá a primeira usina de biodiesel da agricultura familiar.

Disponível em: $<$ http://www.uniara.com.br/ageuniara/artigos.asp?Artigo=4567> . Acesso em: 18 Abr. 2014.

MACEDO, I. C. e NOGUEIRA, L.A.H. Avaliação do biodiesel no

Brasil, Brasília, Distrito Federal, jul. 2004. 
MACHADO, M. F. et al. Estudo do crambe (Crambe abyssinica) como fonte de óleo para produção de biodiesel. In: II Congresso da Rede Brasileira de Tecnologia de Biodiesel, Anais, Brasília. 2007. Disponível em: <http://www.enerbio.ind.br/wpcontent/uploads/2011/05/Artigo_Crambe_RBTB.pdf >. Acesso em: 12 jan. 2013. MARCHETTI, J.M.; MIGUEL, V.U.; ERRAZU, A.F., Possible Methods for Biodiesel Production. Renewable \& Sustainable Energy Reviews, v.11, p.1300-1311, 2007.

MATARAZZO, D.C. Análise financeira de balanços. 5. Ed. São Paulo: Atlas, 1998.

MATHIAS, W.F. Administração financeira e orçamentária. São Paulo: Atlas, 2009.

MEIRELLES, F.S. Biodiesel. Brasília. 2003. Disponível em

<http:www.faespsenar.com.br/faesp/econômico/EstArtigos/>. Acesso em: 10 set. 2012.

MENDES, D.B.Glicerina: uma abordagem sobre a produção e o tratamento. 2012. Disponível em: <http://www.liberato.com.br/upload/arquivos/0107121220302827.pdf>. Acesso em: 16 maio. 2014

METHANEX. Disponível em: <http://www.methanex.com>. Acesso em: 7 abr.2014.

MING, C. À procura do grão ideal. biocombustíveis em foco. Ano 1, n. 2, fev. 2009. Disponível em:

$<$ http://www.iica.org.br/Docs/Publicacoes/Agronegocio/2009/Biocombustiveis_em_FOCO -AnoI-N002.pdf $>$. Acesso em: 09 mar. 2013.

MME- Ministério de Minas e Energia,2010. Disponível em<http://www.mme.gov.br/mme.Acesso em: 15 jul. 2013.

OLIVEIRA, L.B., COSTA, A.O. Biodiesel: uma experiência de desenvolvimento sustentável. IVIG/COPPE/UFRJ. 2001.

OLIVEIRA, P.F. de. 2010. Níveis de inclusão na suplementação de. bovinos de corte. Disponível em:

$<$ http://zootecnia.jatai.ufg.br/uploads/186/original_POLYANA_FURTADO_DE_OLIVEI RA.pdf>. Acesso em: 16 maio. 2014.

OLIVEIRA, V.F. de et al. , Estudo do equilíbrio de adsorção da torta prensada de crambe (crambe abyssinica) em sua aplicação como biosorvente em soluções aquosas de corante. Disponível em:

http://www.cobeqic2009.feq.ufu.br/uploads/media/91415611.pdf $>$. Acesso em: 16 maio. 2014.

PARENTE, E.J. de S. Biodiesel: uma aventura tecnológica num país engraçado. Fortaleza. Tecbio/Nutec, 2003.

PILÃO, N. E.; VAMPRÉ, P.R. Matemática Financeira e Engenharia Econômica. São Paulo: Cengage Learning, 2003. 273 p. 
PITOL, C.; BROCH, D. L.; ROSCOE, R. Efeito do espaçamento e densidade de plantio sobre a produtividade do crambe cv. FMS Brilhante. In: CONGRESSO BRASILEIRO DE MAMONA. 2010. p. 1339-1344. Disponível em:

$<$ http://www.cbmamona.com.br/pdfs/MAN-37.pdf $>$. Acesso em: 12 jan. 2013

PORTAL BRASIL, 2014. Disponível em: <http://www.portalbrasil.net/igpm.html>. Acesso em: 20 mar.2014.

PNPB - Plano de Uso e Produção de Biocombustíveis. 2005. Disponível em: <http:// www.biodiesel.gov.br. > Acesso em: 11 ago. 2012.

QUINTELLA, C.M.; TEIXEIRA, L.S.G.; KORN, M.G.A.; NETO, P.R.C.; TORRES, E.A.; CASTRO, M.P.; JESUS, C.A.C. Cadeia do biodiesel da bancada à indústria: uma visão geral com prospecção de tarefas e oportunidades para P\&D\&I. Química Nova, v.32, n³, p.793-808, 2009.

RECEITA FEDERAL, 2014. Disponível em: <http://

www.receita.fazenda.gov.br/legislação/ins/Ant2001/1998/in16298ane1.htm. > Acesso em: 08 abr. 2014.

ROSS, S.A.; WESTERFIELD, R.W.; JAFFE, J.F. Administração financeira: corporate finance. São Paulo: Atlas, 2007.

SANVICENTE, A.Z. Princípios da Administração Financeira. São Paulo: Atlas, 1998.

SAMANEZ, C.P. Engenharia Econômica. São Paulo: Pearson Prentice Hall, 2009. 211p.

SELIC , Sistema especial de liquidação e de custódia. 2014. Disponível em: < http:// www.bcb.gov.br >. Acesso em: 08 maio.. 2014.

SILVA, J.de. Administração financeira e orçamentária. São Paulo: Atlas, 2006.

SILVA, P. R. F. da; FREITAS, T. F. S de. Biodiesel: o ônus e o bônus de produzir combustível. Ciência Rural. Santa Maria, v. 38, n. 3, maio-jun, 2008. Disponível em: $<$ http://www.scielosp.org/pdf/cr/v38n3/a44v38n3.pdf>. Acesso em: 10 abr.2013.

SILVA, R.B. da. Substituição de farelo de soja por torta de crambe para ovinos em crescimento. 2013.Disponível em:

$<$ http//www.repositorio.ufla.br/.../DISSERTAÇÃO_Substituição\%20de\%20farelo\%20...>. Acesso em 16 maio. 2014

SOARES J, et al., Potencial da torta de crambe para produção de etanol. Disponível em: $<$ http://www.enerbio.ind.br/wp-content/uploads/2011/05/614-Potencial-da-Torta-deCrambe.pdf>. Acesso em: 16 maio. 2014.

SOUZA et al., Estudo de viabilidade de implantação de umamicro usina produtora de biodiesel na micro região de campo mourão. Disponível em:

$<$ http://www.abepro.org.br/biblioteca/ENEGEP 2007_TR590444_9419>. Acesso 27 mar. 2014. 
SUAREZ, P. A. Z, et al., Biocombustíveis a partir de óleos e gorduras: desafios tecnológicos para viabilizá-los. Instituto de Química, Universidade de Brasília, Brasília, DF, v. 32, n. 3, mar. 2009. Disponível em:

$<$ http://www.scielo.br/scielo.php?script=sci pdf\&pid=S0100-

40422009000300020\&lng=en\&nrm=iso\&tlng=pt $>$. Acesso em Jun. 2010.

SCHNEIDER, S. Desenvolvimento Rural Regional e articulações extra-regionais. In: Anais do I Fórum Internacional: Território, Desenvolvimento Rural e Democracia. Fortaleza-CE, 16 a 19 de novembro 2003.

TURRA, F. E. Analise de diferentes métodos de calculo de custos de produção na agricultura brasileira. Piracicaba, 1990. 134 f. Dissertação (Mestrado) - Escola Superior de Agricultura "Luiz de Queiroz”, Universidade de São Paulo, Piracicaba.

TRZECIAK, M. B, at al. Utilização de sementes de espécies oleaginosas para produção de biodiesel. 2008. Disponível em:

$<$ http://www.ufvjm.edu.br/disciplinas/agr011/files/2013/10/biodiesel.pdf $>$. Acesso em: 10 abr. 2014.

VEIGA, J. E. da. Territórios para um desenvolvimento sustentável. 2006. Disponível em: <http://cienciaecultura.bvs.br/pdf/cic/v58n1/a12v58n1.pdf. $>$. Acesso em: 10 jan. 2014.

VEIGA, J. E. da. O Brasil rural ainda não encontrou seu eixo de desenvolvimento.

Estudos Avançados, v. 15, n. 43, p. 101-119, 2001. Disponível em:

$<$ http://www.scielo.br/pdf/ea/v15n43/v15n43a10.pdf $>$. Acesso em: 10 jan. 2014.

WANDERLEY, N. Raízes históricas do campesinato brasileiro. In: TEDESCO (Org.) Agricultura familiar: realidades e perspectivas. Passo Fundo- RS: UPF, 2001, 405 p. 


\section{APÊNDICE}

Apêndice 1

\section{DESPESAS DE INVESTIMENTOS}

\section{DADOS}

Considerando que o imóvel avaliado refere-se a uma instalação rural de imóvel rústico, sem forro, fechado em duas laterais, sem esquadrias, pintura, com instalações elétricas e hidráulicas simples, etc., o custo unitário adotado será de $40 \%$ do valor por metro quadrado, ou seja, 0,40 vezes $\mathrm{R} \$ 1.180,94$ é igual a $\mathrm{R} \$ 472,38 \mathrm{~m}^{2}$, sendo utilizado para este projeto um barracão de $64 \mathrm{~m}^{2}$ vezes $\mathrm{R} \$ 472,38$, obtém-se um investimento de $\mathrm{R} \$$ $30.232,32$.

\section{USINA CAPACIDADE DE 44 LITROS}

Investimentos Iniciais

$$
\text { Categoria }
$$

Valores

Máquinas e Equipamentos

Usina de Biodiesel Cap. 44 litros

$\mathrm{R} \$ 108.500,0000$

Instalações

Barracão de 64 m2

$\mathrm{R} \$ \quad 30.232,3200$

Total Geral

R\$ 138.732,3200

USINA CAPACIDADE DE 66 LITROS

Investimentos Iniciais

Categoria

Valores

Máquinas e Equipamentos

Usina de Biodiesel Cap. 66 litros

$\mathrm{R} \$ 116.700,0000$

Instalações

Barracão de 64 m2

$\mathrm{R} \$ \quad 30.232,3200$

Total Geral

R\$ 146.932,3200 
USINA CAPACIDADE DE 110 LITROS

Investimentos Iniciais

Categoria

Máquinas e Equipamentos

Instalações

Total Geral
Valores

Usina de Biodiesel Cap. 110 litros

Barracão de $64 \mathrm{~m} 2$

$\mathrm{R} \$ \quad 30.232,3200$

R\$ 156.232,3200 
Apêndice 2

\author{
RECEITAS MENSAIS
}

USINA CAPACIDADE DE 44 LITROS

\title{
DADOS
}

Para Produzir 1 litro de óleo de crambe utiliza 2,682 $\mathrm{Kg}$ de semente de crambe e resulta em torta de crambe $1,682 \mathrm{Kg}$ e corresponde a teor de óleo $(37,29 \%)$ e torta de crambe $(62,72 \%)$.

1 litro de biodiesel pago pelos leilões (quantidade 20 leilões) preço médio: R\$ 2,2299.

$1 \mathrm{Kg}$ de torta de crambe pago pelas empresas preço médio $=\mathbf{R} \mathbf{0 , 5 1 2 9}$.

1 litro de glicerol pago pelas empresas preço médio $=\mathbf{R} \mathbf{0 , 6 0 2 0}$.

\section{PRODUÇÃO}

40 litros de biodiesel $\times 06$ bateladas $=240$ litros dia $\times 22$ dias ao mês $=\mathbf{5 2 8 0}$ litros de biodiesel (Mês).

4 litros de glicerol x 06 bateladas $=24$ litros dia $\times 22$ dias ao mês $=\mathbf{5 2 8}$ litros de glicerol (Mês).

1 litro de óleo $=1,682 \mathrm{~kg}$ de torta de crambe $(5280$ litros de biodiesel $\times 1,682 \mathrm{Kg}=$ 8.880,96 (Kg)).

\section{RECEITAS MENSAIS}

\section{Descriminação Unidades Valores ( R\$ ) Quantidade Valor Total ( R\$ )}

$\begin{array}{lcrrr}\text { Biodiesel } & \mathrm{L} & 2,2299 & 5.280 & 11.773,8720 \\ \text { Glicerol } & \mathrm{L} & 0,6020 & 528 & 317,8560 \\ \text { Torta de crambe } & \mathrm{Kg} & 0,5129 & 8.880,96 & 4.555,0444 \\ \text { TOTAL } & & & & \mathbf{1 6 . 6 4 6 , 7 7 2 4}\end{array}$


Apêndice 3

\author{
RECEITAS MENSAIS
}

USINA CAPACIDADE DE 66 LITROS

\title{
DADOS
}

Para Produzir 1 litro de óleo de crambe utiliza 2,682 $\mathrm{Kg}$ de semente de crambe e resulta em torta de crambe $1,682 \mathrm{Kg}$ e corresponde a teor de óleo $(37,29 \%)$ e torta de crambe $(62,72 \%)$.

1 litro de biodiesel pago pelos leilões (quantidade 20 leilões) preço médio: R\$ 2,2299.

$1 \mathrm{Kg}$ de torta de crambe pago pelas empresas preço médio $=\mathbf{R} \mathbf{0 , 5 1 2 9}$.

1 Litro de glicerol pago pelas empresas preço médio $=\mathbf{R} \$ \mathbf{0 , 6 0 2 0}$.

\section{PRODUÇÃO}

40 litros de biodiesel $\times 06$ bateladas $=240$ litros dia $\times 22$ dias ao mês $=7920$ litros de biodiesel (Mês).

4 litros de glicerol x 06 bateladas $=24$ litros dia $\times 22$ dias ao mês $=792$ litros de glicerol (Mês).

1 litro de óleo $=1,682 \mathrm{~kg}$ de torta de crambe $(5280$ litros de biodiesel $\times 1,682 \mathrm{Kg}=$ 13.321,44 (Kg)).

\section{RECEITAS MENSAIS}

\section{Descriminação Unidades Valores ( R\$ ) Quantidade Valor Total ( R\$ )}

$\begin{array}{llrrr}\text { Biodiesel } & \mathrm{L} & 2,2299 & 7.920 & 17.660,8080 \\ \text { Glicerol } & \mathrm{L} & 0,6020 & 792 & 476,7840 \\ \text { Torta de crambe } & \mathrm{Kg} & 0,5129 & 13.321,44 & 6.832,5666 \\ \text { TOTAL } & & & & \mathbf{2 4 . 9 7 0 , 1 5 8 6}\end{array}$


Apêndice 4

\author{
RECEITAS MENSAIS
}

USINA CAPACIDADE DE 110 LITROS

\title{
DADOS
}

Para Produzir 1 litro de óleo de crambe utiliza 2,682 $\mathrm{Kg}$ de semente de crambe e resulta em torta de crambe $1,682 \mathrm{Kg}$ e corresponde a teor de óleo $(37,29 \%)$ e torta de crambe $(62,72 \%)$.

1 Litro de biodiesel pago pelos leilões (quantidade 20 leilões) preço médio: R\$ 2,2299.

$1 \mathrm{Kg}$ de torta de crambe pago pelas empresas preço médio $=\mathbf{R} \mathbf{0 , 5 1 2 9}$.

1 Litro de glicerol pago pelas empresas preço médio $=\mathbf{R} \$ \mathbf{0 , 6 0 2 0}$.

\section{PRODUÇÃO}

40 litros de biodiesel $\times 06$ bateladas $=240$ litros dia $\times 22$ dias ao mês $=\mathbf{1 3 2 0 0}$ litros de biodiesel (Mês).

4 litros de glicerol x 06 bateladas $=24$ litros dia $\times 22$ dias ao mês $=\mathbf{1 3 2 0}$ litros de glicerol (Mês).

1 litro de óleo $=1,682 \mathrm{~kg}$ de torta de crambe $(5280$ litros de biodiesel $\times 1,682 \mathrm{Kg}=$ 22.202,24 (Kg)).

\section{RECEITAS MENSAIS}

\section{Descriminação Unidades Valores ( R\$ ) Quantidade Valor Total ( R\$ )}

$\begin{array}{llrrr}\text { Biodiesel } & \mathrm{L} & 2,2299 & 13.200 & 29.434,6800 \\ \text { Glicerol } & \mathrm{L} & 0,6020 & 1.320 & 794,6400 \\ \text { Torta de crambe } & \mathrm{Kg} & 0,5129 & 22.202,24 & 11.387,5289 \\ \text { TOTAL } & & & & \mathbf{4 1 . 6 1 6 , 8 4 8 9}\end{array}$


Apêndice 5

CUSTOS MENSAIS

USINA CAPACIDADE DE 44 LITROS

\section{DADOS}

1 litro de óleo de crambe custa: $\mathbf{R} \mathbf{2 , 0 3 8 9 .}$

1 Litro de biodiesel pago pelos leilões (quantidade 20 leilões) preço médio: R\$ 2,2299.

1 litro de metanol custa: $\mathbf{R} \$ \mathbf{0 , 9 1 9 8 .}$

$1 \mathrm{Kg}$ de hidróxido de sódio custa: $\mathbf{R} \mathbf{1 2 , 0 0}$.

Energia elétrica $700 \mathrm{w} / \mathrm{h}$ por hora - $1 \mathrm{Kw} / \mathrm{h}$ custa: $\mathbf{R} \mathbf{0 , 3 8 1 5}$.

Mão de obra dados do Instituto de Economia Agrícola 04/04/2014 - mensalista custa: R\$ $1.250,00 \times 1,62=\mathbf{R} \$ \mathbf{2 . 0 2 5 , 0 0}$.

Para produzir 1 litro de óleo de crambe utiliza $\mathbf{2 , 6 8 2} \mathrm{Kg}$ de semente de crambe e resulta em torta de crambe $\mathbf{1 , 6 8 2} \mathbf{K g}$.

Nota: Em uma usina com capacidade de 44 Litros (Produz 40 litros de biodiesel e 4 litros de glicerol).

Produção: A cada 1h20min é produzido uma batelada (ao dia se produz 06 bateladas 08 horas diárias e $12 \mathrm{hs}$ para decantação).

\section{PRODUÇÃO}

40 litros de biodiesel $\times 06$ bateladas $=240$ litros dia $\times 22$ dias ao mês $=\mathbf{5 2 8 0}$ litros de biodiesel (Mês).

4 litros de Glicerol x 06 bateladas $=24$ litros dia $\times 22$ dias ao mês $=\mathbf{5 2 8}$ litros de glicerol (Mês).

\section{CUSTOS MENSAIS}

Óleo de crambe

Litros Preço Total

$\begin{array}{lll}5280 & \mathrm{R} \$ 2,0389 & \mathbf{1 0 . 7 6 5 , 3 9 2 0}\end{array}$ 
Metanol (a cada 1 litro usa $90 \mathrm{ml}$ de metanol 5280 x $90=475,2$ litros).

Litros Preço Total

$\begin{array}{lll}475,2 & \mathrm{R} \$ 0,9198 & \mathbf{4 3 7 , 0 8 9 0}\end{array}$

Hidróxido sódio (a cada 1 litro de óleo usa 1\% de hidróxido de sódio $=10 \mathrm{~g}$ o $\mathrm{Kg}$ custa $R \$ 12,00)$.

Litros Preço Total

$\begin{array}{lll}5280 & \mathrm{R} \$ 0,12 & \mathbf{6 3 3 , 6 0 0 0}\end{array}$

Energia elétrica consumo de uma hora de processo 700w/h x 8 horas $=5,6 \mathrm{kw}(1 \mathrm{Kw}$ custa $R \$ 0,3815$, então $5,6 \mathrm{kw} \times 0,3815=R \$ 2,1364$ ao dia $\times 22$ dias $=R \$ 47,00=(5,6$ Kw ao dia $x 22$ dias $=123,2 \mathrm{kw})$ ).

KW Preço Total

$\begin{array}{lll}123,2 & \mathrm{R} \$ 0,38 & \mathbf{4 7 , 0 0 0 8}\end{array}$

Mão de obra mensal ( Fonte IEA de 04/04/2014 R\$ 1250,00 mensalista x 1,62 ).

Funcionário $\quad$ Preço Total

$1 \quad \mathrm{R} \$ 2.025,00 \quad \mathbf{2 0 2 5 , 0 0 0 0}$

Tanque de decantação cap. 1000 Litros

Quantidade Preço Total

$1 \quad \mathrm{R} \$ 249,90 \quad \mathbf{2 4 9 , 9 0 0 0}$

Depreciação (Usina 10 anos valor $R \$ 108.500,00$ dividido em 120 meses $=R \$ 904,17$ ) $\mathrm{e}$ (barracão de $64 \mathrm{~m} 225$ anos valor de $R \$ 30.232,32$ dividido em 300 meses $=R \$ 100,77$ sendo o total da depreciação $=R \$ 1.004,94)$.

Depreciação Preço Total

Usina e Barracão $\quad \mathrm{R} \$ 1.004,94 \quad \mathbf{1 . 0 0 4 , 9 4 0 0}$

\section{CUSTOS MENSAIS}

Descriminação Unidades Valores (R\$) Quantidade Valor total ( R\$ )

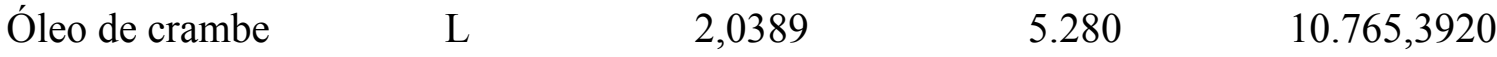

$\begin{array}{lllll}\text { Metanol } & \text { L } & 0,9198 & 475,2 & 437,0890\end{array}$ 


\begin{tabular}{llrrr} 
Hidróxido de sódio & \multicolumn{1}{l}{ Kg } & 0,12 & 5.280 & 633,6000 \\
Tanque de decantação & \multicolumn{1}{l}{ L } & 249,9000 & 1 & 249,9000 \\
Energia elétrica & KWh/mês & 0,3815 & 123,2 & 47,0008 \\
Mão de obra & No Func. & $2.025,0000$ & 1 & $2.025,0000$ \\
Depreciação & R $\$$ & $1.004,9400$ & 2 & $1.004,9400$
\end{tabular}

TOTAL

$15.162,9218$

NOTA: Para produzir 5280 litros de óleo necessito:

Para Produzir 5280 litros de óleo mês necessito de 14.160,2733

Kg de semente de crambe.

Para Produzir 14.160,2733 Kg é necessário uma área territorial de 9,39602 hectares. 
Apêndice 6

CUSTOS MENSAIS

USINA CAPACIDADE DE 66 LITROS

\section{DADOS}

1 litro de óleo de crambe custa: $\mathbf{R} \mathbf{2 , 0 3 8 9 .}$

1 litro de biodiesel pago pelos leilões (quantidade 20 leilões) preço médio: $\mathbf{R} \mathbf{2 , 2 2 9 9}$.

1 litro de metanol custa: $\mathbf{R} \$ \mathbf{0 , 9 1 9 8 .}$

$1 \mathrm{Kg}$ de hidróxido de sódio custa: $\mathbf{R} \mathbf{1 2 , 0 0}$.

Energia elétrica $700 \mathrm{w} / \mathrm{h}$ por hora - $1 \mathrm{Kw} / \mathrm{h}$ custa: $\mathbf{R} \mathbf{0 , 3 8 1 5}$.

Mão de obra dados do Instituto de Economia Agrícola 04/04/2014 - mensalista custa: R\$ $1.250,00 \times 1,62=\mathbf{R} \$ \mathbf{2 . 0 2 5 , 0 0}$.

Para Produzir 1 Litro de óleo de crambe utiliza 2,682 Kg de semente de crambe e resulta em torta de crambe $\mathbf{1 , 6 8 2} \mathbf{~ K g}$.

Nota: Em uma usina com capacidade de 66 Litros (Produz 60 litros de biodiesel e 6 litros de glicerol).

Produção: A cada 1h20min é produzido uma batelada (ao dia se produz 06 bateladas 08 horas diárias e $12 \mathrm{hs}$ para decantação).

\section{PRODUÇÃO}

60 litros de biodiesel $\times 06$ bateladas $=360$ litros dia $\times 22$ dias ao mês $=7920$ litros de biodiesel (Mês).

6 litros de Glicerol x 06 bateladas $=36$ litros dia $\times 22$ dias ao mês $=792$ litros de glicerol (Mês).

\section{CUSTOS MENSAIS}

Óleo de crambe

Litros Preço Total
7920
$\mathrm{R} \$ 2,0389$
$16.148,0880$ 
Metanol (a cada 1 litro usa $90 \mathrm{ml}$ de metanol 7920 x $90=712,8$ litros).

Litros Preço Total

$\begin{array}{lll}712,8 & \mathrm{R} \$ 0,9198 & \mathbf{6 5 5 , 6 3 3 4}\end{array}$

Hidróxido sódio (a cada 1 litro de Óleo usa $1 \%$ de hidróxido de sódio $=10 \mathrm{~g}$ o $\mathrm{Kg}$ custa $R \$ 12,00)$.

Litros Preço Total

$\begin{array}{lll}7920 & \mathrm{R} \$ 0,12 & \mathbf{9 5 0 , 4 0 0 0}\end{array}$

Energia elétrica consumo de uma hora de processo 700w/h 8 horas $=5,6 \mathrm{kw}(1 \mathrm{Kw}$ custa $R \$ 0,3815$, então $5,6 \mathrm{kw} \times 0,3815=R \$ 2,1364$ ao dia $\times 22$ dias $=R \$ 47,00=(5,6$ Kw ao dia $x 22$ dias $=123,2 \mathrm{kw})$ ).

KW Preço Total

$\begin{array}{lll}123,2 & \mathrm{R} \$ 0,38 & \mathbf{4 7 , 0 0 0 8}\end{array}$

Mão de obra mensal ( Fonte IEA de 04/04/2014 R\$ 1250,00 mensalista x 1,62 ).

Funcionário $\quad$ Preço Total

$1 \quad \mathrm{R} \$ 2.025,00 \quad \mathbf{2 0 2 5 , 0 0 0 0}$

Tanque de Decantação cap. 1000 Litros

Quantidade Preço Total

$1 \quad \mathrm{R} \$ 249,90 \quad \mathbf{2 4 9 , 9 0 0 0}$

Depreciação (Usina 10 anos valor $R \$ 116.700,00$ dividido em 120 meses $=R \$ 972,50$ ) e (Barracão de $64 \mathrm{~m} 225$ anos valor de $R \$ 30.232,32$ dividido em 300 meses $=R \$ 100,77$ sendo o total da depreciação $=\mathbf{R} \$ 1.073,27)$.

Depreciação Preço Total

Usina e Barracão $\quad \mathrm{R} \$ 1.073,27 \quad \mathbf{1 . 0 7 3 , 2 7 0 0}$

\section{CUSTOS MENSAIS}

Descriminação Unidades Valores (R\$) Quantidade Valor total ( R\$ )

$\begin{array}{lllll}\text { Óleo de crambe } & \text { L } & 2,0389 & 7.920 & 16.148,0880\end{array}$

Metanol

L $\quad 0,9198 \quad 712,8$

655,6334 


\begin{tabular}{llrrr} 
Hidróxido de sódio & \multicolumn{1}{l}{ Kg } & 0,12 & 7.920 & 950,4000 \\
Tanque de decantação & \multicolumn{1}{l}{ L } & 249,9000 & 1 & 249,9000 \\
Energia elétrica & KWh/mês & 0,3815 & 123,2 & 47,0008 \\
Mão de obra & N Func. & $2.025,0000$ & 1 & $2.025,0000$ \\
Depreciação & R $\$$ & $1.073,2700$ & 2 & $1.073,2700$ \\
TOTAL & & & & $\mathbf{2 1 . 1 4 9 , 2 9 2 2}$
\end{tabular}

NOTA: Para produzir 7920 litros de óleo necessito:

Para Produzir 7920 litros de óleo mês necessito de $\mathbf{2 1 . 2 4 0 , 4 1 0 0}$ Kg de semente de crambe.

Para Produzir 35.400,6800 Kg é necessário uma área territorial de 14,0940 hectares. 
Apêndice 7

CUSTOS MENSAIS

USINA CAPACIDADE DE 110 LITROS

\section{DADOS}

1 litro de óleo de crambe custa: $\mathbf{R} \mathbf{2 , 0 3 8 9}$.

1 Litro de biodiesel pago pelos leilões (quantidade 20 leilões) preço médio: $\mathbf{R} \mathbf{2 , 2 2 9 9}$.

1 litro de metanol custa: $\mathbf{R} \$ \mathbf{0 , 9 1 9 8 .}$

$1 \mathrm{Kg}$ de hidróxido de sódio custa: $\mathbf{R} \mathbf{1 2 , 0 0}$.

Energia elétrica $700 \mathrm{w} / \mathrm{h}$ por hora - $1 \mathrm{Kw} / \mathrm{h}$ custa: $\mathbf{R} \mathbf{0 , 3 8 1 5}$.

Mão de obra dados do Instituto de Economia Agrícola 04/04/2014 - mensalista custa: R\$ $1.250,00 \times 1,62=\mathbf{R} \$ \mathbf{2 . 0 2 5 , 0 0}$.

Para Produzir 1 Litro de óleo de crambe utiliza 2,682 Kg de semente de crambe e resulta em torta de crambe $\mathbf{1 , 6 8 2} \mathbf{K g}$.

Nota: Em uma usina com capacidade de 110 Litros (Produz 100 litros de biodiesel e 10 litros de Glicerol).

Produção: A cada 1h20min é produzido uma batelada (ao dia se produz 06 bateladas 08 horas diárias e $12 \mathrm{hs}$ para decantação).

\section{PRODUÇÃO}

100 litros de biodiesel $\times 06$ bateladas $=600$ litros dia $\times 22$ dias ao mês $=\mathbf{1 3 2 0 0}$ litros de biodiesel (Mês).

10 litros de Glicerol x 06 bateladas $=60$ litros dia $\times 22$ dias ao mês $=\mathbf{1 3 2 0}$ litros de glicerol (Mês).

\section{CUSTOS MENSAIS}

Óleo de crambe

Litros Preço Total
13200
$\mathrm{R} \$ 2,0389$
$26.913,4800$ 
Metanol (a cada 1 litro usa $90 \mathrm{ml}$ de metanol 13200 x $90=1188$ litros).

Litros Preço Total

$\begin{array}{lll}1188 & \mathrm{R} \$ 0,9198 & \mathbf{1 0 9 2 , 7 2 7 4}\end{array}$

Hidróxido sódio (a cada 1 litro de Óleo usa $1 \%$ de hidróxido de sódio $=10 \mathrm{~g}$ o $\mathrm{Kg}$ custa $R \$ 12,00)$.

Litros Preço Total

$\begin{array}{lll}13200 & \mathrm{R} \$ 0,12 & \mathbf{1 5 8 4 , 0 0 0 0}\end{array}$

Energia elétrica consumo de uma hora de processo 700w/h $x 8$ horas $=5,6 \mathrm{kw}(1 \mathrm{Kw}$ custa $R \$ 0,3815$, então $5,6 \mathrm{kw} \times 0,3815=R \$ 2,1364$ ao dia $\times 22$ dias $=R \$ 47,00=(5,6$ Kw ao dia $x 22$ dias $=123,2 \mathrm{kw})$ ).

KW Preço Total

$\begin{array}{lll}123,2 & \mathrm{R} \$ 0,38 & \mathbf{4 7 , 0 0 0 8}\end{array}$

Mão de obra mensal ( Fonte IEA de 04/04/2014 R\$ 1250,00 mensalista x 1,62 ).

Funcionário $\quad$ Preço Total

$1 \quad \mathrm{R} \$ 2.025,00 \quad \mathbf{2 0 2 5 , 0 0 0 0}$

Tanque de decantação cap. 1000 Litros

Quantidade Preço Total

$1 \quad \mathrm{R} \$ 249,90 \quad \mathbf{2 4 9 , 9 0 0 0}$

Depreciação (Usina 10 anos valor $R \$ 126.000,00$ dividido em 120 meses $=R \$ 1050,50$ ) e (Barracão de $64 \mathrm{~m} 225$ anos valor de $R \$ 30.232,32$ dividido em 300 meses $=R \$$ $100,77$ sendo o total da depreciação $=R \$ 1.150,77)$.

Depreciação Preço Total

Usina e Barracão $\quad \mathrm{R} \$ 1.150,77 \quad \mathbf{1 . 1 5 0 , 7 7 0 0}$

\section{CUSTOS MENSAIS}

Descriminação Unidades Valores (R\$) Quantidade Valor total ( RS )

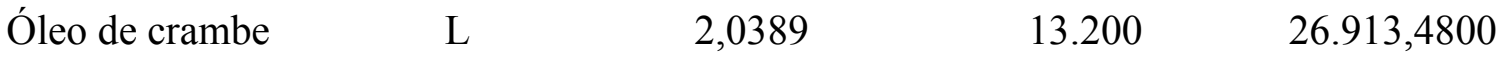

$\begin{array}{lllll}\text { Metanol } & \text { L } & 0,9198 & 1188 & 1.092,7224\end{array}$ 
Hidróxido de sódio $\quad \mathrm{Kg}$

0,12

13.200

$1.584,0000$

Tanque de decantação

L

249,9000

1

249,9000

Energia elétrica

KWh/mês

0,3815

123,2

47,0008

Mão de obra

$\mathrm{N}^{\circ}$ Func. $\quad 2.025,0000$

1

$2.025,0000$

Depreciação

$\mathrm{R} \$ \quad 1.150,7700$

2

$1.150,7700$

TOTAL

33.062,8732

NOTA: Para produzir 13200 litros de óleo necessito:

Para Produzir 13200 litros de óleo mês necessito de 35.400,6800 Kg de semente de crambe.

Para Produzir 35.400,6800 Kg necessito de uma área territorial de $\mathbf{2 3 , 4 9 0 1}$ hectares. 